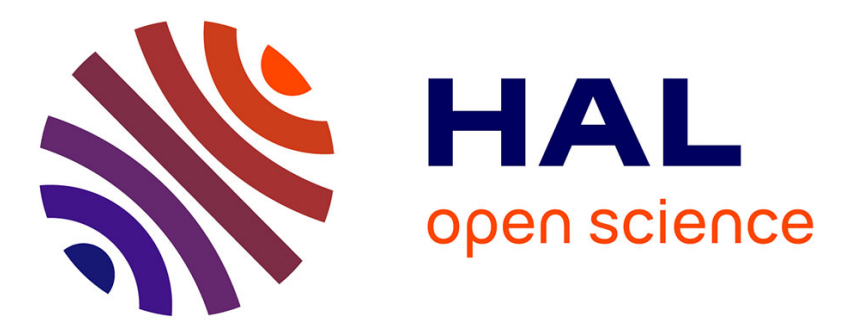

\title{
Interaction of (3-Aminopropyl)triethoxysilane with Pulsed Ar-O 2 Afterglow: Application to Nanoparticles Synthesis
}

\author{
M. M. Gueye, T. Gries, C Noel, S. Migot-Choux, S. Bulou, E. Lecoq, P. \\ Choquet, K. Kutasi, T. Belmonte
}

\section{To cite this version:}

M. M. Gueye, T. Gries, C Noel, S. Migot-Choux, S. Bulou, et al.. Interaction of (3Aminopropyl)triethoxysilane with Pulsed Ar-O 2 Afterglow: Application to Nanoparticles Synthesis. Plasma Chemistry and Plasma Processing, 2016, 36, pp.1031-1050. 10.1007/s11090-016-9708-3 . hal-02113599

\section{HAL Id: hal-02113599 \\ https://hal.science/hal-02113599}

Submitted on 14 May 2019

HAL is a multi-disciplinary open access archive for the deposit and dissemination of scientific research documents, whether they are published or not. The documents may come from teaching and research institutions in France or abroad, or from public or private research centers.
L'archive ouverte pluridisciplinaire $\mathbf{H A L}$, est destinée au dépôt et à la diffusion de documents scientifiques de niveau recherche, publiés ou non, émanant des établissements d'enseignement et de recherche français ou étrangers, des laboratoires publics ou privés. 


\title{
Interaction of (3-Aminopropyl)triethoxysilane with pulsed $\mathrm{Ar}-\mathrm{O}_{2}$
}

\section{afterglow: Application to nanoparticles synthesis}

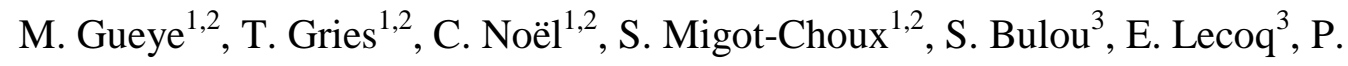 \\ Choquet $^{3}$, K. Kutasi ${ }^{4}$, T. Belmonte ${ }^{1,2}$
}

${ }^{1}$ Université de Lorraine, Institut Jean Lamour, UMR CNRS 7198, NANCY, F-54011, France

${ }^{2}$ CNRS, Institut Jean Lamour, UMR CNRS 7198, NANCY, F-54011, France

${ }^{3}$ Luxembourg Institute of Science and Technology, 41 rue du Brill, L-4422 Belvaux, Luxembourg

${ }^{4}$ Institute for Solid State Physics and Optics, Wigner Research Centre for Physics, Hungarian Academy of Sciences, POB 49, H-1525 Budapest, Hungary

* corresponding author. Email: thierry.belmonte@ @univ-lorraine.fr

Keywords: (3-Aminopropyl)triethoxysilane, oxygen afterglow, plasma polymer, nanoparticles. 


\begin{abstract}
The interaction of (3-Aminopropyl)triethoxysilane (APTES) with pulsed late $\mathrm{Ar}-\mathrm{O}_{2}$ afterglow is characterized by the synthesis of $\mathrm{OH}, \mathrm{CO}$ and $\mathrm{CO}_{2}$ in the gas phase as main by-products. Other minor species like $\mathrm{CH}, \mathrm{CN}$ and $\mathrm{C}_{2} \mathrm{H}$ are also produced. We suggest that $\mathrm{OH}$ radicals are produced in a first step by dehydrogenation of APTES after interaction with oxygen atoms. In a second step, the molecule is oxidized by any $\mathrm{O}_{2}$ state, to form peroxides that transform into by-products, break thus the precursor $\mathrm{C}-\mathrm{C}$ bonds. If oxidation is limited, i.e. a low duty cycle, fragmentation of the precursor is limited and produced nanoparticles keep the backbone structure of the precursor, but contain amide groups produced from the amine groups initially available in APTES. At high duty cycle, silicon-containing fragments contain some carbon and react together and produce nanoparticles with a non-silica-like structure.
\end{abstract}




\section{INTRODUCTION}

The elaboration of new functional coatings on inorganic surfaces by biomimetic using green technologies can be considered as a real breakthrough in the world of metallic alloys manufacturers. In particular, biological molecules strongly chemically bonded to a metallic surface could provide to a flat product interesting features such as natural lubricant, antibiocorrosion or antifouling properties [1-5]. However, any broad development of these revolutionary "biocoatings" requires an excellent control at nanoscale of the chemical functional groups that constitute the coating.

Plasma deposition processes are well known to produce improved surface stability, controlled chemical functionality and topography [6-10]. They can be considered as the best industrial technique platform to realize, on each type of inorganic surfaces - and especially on metallic surfaces - an inorganic/organic interlayer for the covalent bonding of biomolecules [11-13]. Plasma polymerisation is a process able to produce conformal, pin-hole free, highly crosslinked polymers. The main interest of this process here is to offer the advantage of not only providing a high adhesion level with the native oxide/hydroxide layer of the metallic surface but also assisting the chemical deposition of a stable layer with highly reactive chemical groups to further promote the immobilization of biomolecules. Both features are nevertheless controlled by the choice of the precursor that must be designed so as to include suited chemical groups.

Among the different functional groups, primary amines $\left(-\mathrm{NH}_{2}\right)$ are interesting owing to their high reactivity towards biomolecules. Thus, $\mathrm{NH}_{2}$-rich polymeric materials can react with biomolecules through the formation of covalent bonds with carboxyl group present in biomolecules such as peptide, enzyme or proteins [14]. Amino-alkoxysilane compounds are widely used in wet chemistry [15] for surface functionalization of oxide materials, particularly for silicon dioxide. Indeed, alkoxy groups can react with hydroxyl groups present on the 
surface of many oxidized materials, and especially metallic alloys, thus forming $-\mathrm{M}-\mathrm{O}-\mathrm{Si}$ covalent bonds with the surface. Thus, a dense siloxane $\mathrm{SiO}_{\mathrm{x}} \mathrm{C}_{\mathrm{y}} \mathrm{H}_{\mathrm{z}}$ layer with a high density of $-\mathrm{NH}_{2}$ groups can combine low permeation and immobilization of biomolecules.

Because of the complexity of plasma polymerization process, it is a challenging task to induce polymerisation of amino-alkoxysilane by creation of $\mathrm{Si}-\mathrm{O}-\mathrm{Si}$ bonds while keeping $-\mathrm{NH}_{2}$ group as such. A strategy chosen by some groups consists in a two-step polymerisation or copolymerisation process. For instance, a two-step plasma process has been used by Jampala et al. [16]. They use HMDSO polymerization in order to deposit a siloxane layer followed by the deposition of pp-ethylenediamine to deposit amino-functionalised coating on stainless steel substrate. These authors noticed that, whereas pp-ethylenediamine readily delaminated from stainless steel substrate, the deposition of an intermediate pp-HMDSO layer strongly enhanced the adhesion of the amino-functionalized plasma polymer. The interest of a copolymerisation process has also been highlighted by other authors for the deposition of aminated coatings on specific polymer surfaces [17-20]. In these works, APTES, i.e. aminopropyltriethoxysilane $\left(\left(\mathrm{C}_{2} \mathrm{H}_{5} \mathrm{O}\right)_{3}-\mathrm{Si}-\mathrm{CH}_{2}-\mathrm{CH}_{2}-\mathrm{CH}_{2}-\mathrm{NH}_{2}\right)$, was used as a monomer for the deposition of a siloxane layer. The group of D.E. Williams showed that the deposition of plasma polymerized ethylenediamine film on cyclo-olefin polymer had a weak adherence. This adherence, as well as the amine surface density, is significantly increased by using copolymerization of EDA and APTES [17, 18]. These authors pointed out that the siloxane network is essential to ensure an efficient amine functionalization.

Avoiding multi-step processes and/or multiple precursors use is a real challenge. Growing in a single step, a siloxane-based thin film functionalized with primary amines using a single amino-alkoxysilane precursor is still under investigation. However, only few articles deal with this issue [5, 19-22], and the majority of these studies point out a rather low amine density of the as-grown thin films and/or do not produce obvious evidences of efficient $-\mathrm{NH}_{2}$ 
functionalization. Indeed, Gubala et al. [19] point out interesting results using APTES as unique precursor but they obtained a lower density compared to the APTES-EDA copolymer thin film [18]. In addition, these articles are focused on the synthesized thin films and do not deal with plasma polymerisation.

In this work, we explain how oxygen active species created in a plasma afterglow, and more precisely oxygen atoms, react with APTES.

\section{EXPERIMENTAL METHOD}

The experimental set-up is depicted in figure 1. A surface wave-driven plasma is ignited in a fused silica tube ( $5 \mathrm{~mm}$ inner diameter) by exposure to $2.45 \mathrm{GHz}$ microwaves launched with a surfatron. The microwave power is set constant at $250 \mathrm{~W}$. The pressure was measured upstream and downstream the flow (points $\mathrm{E}$ and A respectively in figure 1). All the treatments were carried out at $1500 \mathrm{~Pa}$ (downstream pressure in $\mathrm{A}$ ), the upstream pressure being $2000 \mathrm{~Pa}$. The maximum pumping speed of the primary pump was $40 \mathrm{~m}^{3} \mathrm{~h}^{-1}$. The mininum vacuum pressure was $10^{-2}$ mbar. An $\mathrm{Ar}-8.7 \mathrm{vol} . \% \mathrm{O}_{2}$ mixture, flowing at 1150 sccm, is used as plasma gas. In point $\mathrm{C}$ (see figure 1), the plasma tube reaches a 1.2 meter long fused silica tube (16 mm inner diameter) crossed over its whole length by an infrared beam used to probe the afterglow in situ. Liquid APTES (99.0\% purity from Sigma Aldrich) was contained in a temperature-controlled bubbler. Its vapour was transported to the afterglow by an argon flow $(30 \mathrm{sccm})$ through a fused silica tube $(5 \mathrm{~mm}$ inner diameter and $30 \mathrm{~cm}$ in length) connected to the main tube at point B. The APTES partial pressure was determined using the following Antoine's formula established from experimental data obtained by probing the FTIR absorption signal of pure APTES evaporated at temperatures ranging from $300 \mathrm{~K}$ to $390 \mathrm{~K}$ : 


$$
\log _{10}\left(\frac{P_{s}}{P_{r e f}}\right)=1.6-\left(\frac{2384.4}{T(\mathrm{~K})+300}\right)
$$

where $P_{s}$ is the vapour pressure (in $\left.\mathrm{Pa}\right), P_{\text {ref }}$ the standard pressure $(101325 \mathrm{~Pa})$ and $T$ the temperature $(\mathrm{K})$. At $300 \mathrm{~K}, P_{s} / P_{r e f}=4.23 \times 10^{-3}$ and the APTES flow rate was $0.13 \mathrm{sccm}$ in the $\mathrm{Ar}-\mathrm{O}_{2}$ afterglow.

The light emitted by the afterglow was analysed by optical emission spectroscopy (OES). It was collected with an optical fibre connected to $550 \mathrm{~mm}$ focal length monochromator (JobinYvon TRIAX 550) equipped with a 100 grooves $\mathrm{mm}^{-1}$ grating for survey spectra in the range [250-900 nm] and a 1,800 grooves $\mathrm{mm}^{-1}$ grating to record specific transitions with high spectral resolution. The spectrometer was coupled with a HORIBA Jobin-Yvon i-Spectrum Two iCCD detector. Each measurement was averaged over 20 spectra.

In the pulse mode, the discharge was run with a period of $100 \mathrm{~ms}$, the duty cycle varying between 10 and $90 \%$. The average velocity in the afterglow tube was easily deduced from time-resolved OES measurement. A value of $7.1 \pm 0.1 \mathrm{~m} \mathrm{~s}^{-1}$ was found.

FTIR spectroscopy was performed with a commercial Agilent FTIR 680 spectrometer. The infrared beam leaving the spectrometer goes through lenses and collimators to get a parallel beam (16 $\mathrm{mm}$ in diameter). This optical arrangement decreases the intensity of the exiting beam by one order of magnitude typically. The infrared beam was next sent through a $\mathrm{KBr}$ window in the afterglow (single pass) and detected by a remote liquid-nitrogen cooled mercury-cadmium-telluride (MCT) detector which was protected from the afterglow by another $\mathrm{KBr}$ window. To minimize the influence of water and $\mathrm{CO}_{2}$, the infrared path outside the afterglow was continuously flushed by clean, dry and carbon-free air. Absorption spectra were recorded in the range [500-4000 $\mathrm{cm}^{-1}$ ] with a spectral resolution of $2 \mathrm{~cm}^{-1}$. Reference spectra (i.e. either without gas and plasma or with gas but without plasma) were acquired before each acquisition to determine the absorption spectra in afterglow conditions. Each 
measurement was averaged over 100 scans in continuous mode to improve the signal-to-noise ratio.

Nanoparticles were collected on an aluminium substrate located just before the pumping unit. Transmission electron microscopy (TEM) investigation was performed on as-grown nanoparticles with a JEOL ARM 200F - Cold FEG TEM/STEM running at $200 \mathrm{kV}$ (point resolution $0.19 \mathrm{~nm}$ ) fitted with a GIF Quantum ER. Scanning Electron Microscopy (SEM) was made with a Philips XL 30. FTIR measurements on nanoparticles were performed with a commercial Agilent FTIR 680 spectrometer in attenuated total reflection (ATR) mode. Spectra were acquired in the range $\left[500-4000 \mathrm{~cm}^{-1}\right]$ with a spectral resolution of $4 \mathrm{~cm}^{-1}$. X-ray photoelectron spectroscopy (XPS) measurements were performed with a Thermo VG Microlab350 spectrometer using a non-monochromated $\mathrm{Al} \mathrm{K} \alpha$ and $\mathrm{Mg} \mathrm{K} \alpha$ dual anode as $\mathrm{X}$ ray source operated at $300 \mathrm{~W}$ and a Spherical Sector Analyser. Survey spectra to identify elements on the surface were recorded in steps of $1 \mathrm{eV}$ at a $100 \mathrm{eV}$ pass energy. Highresolution spectra of separate photoelectron lines (C 1s, O 1s, Si 2p and N 1s) were taken by steps of $0.05 \mathrm{eV}$ at a constant pass energy of $20 \mathrm{eV}$. The normal operation pressure was $5 \times 10^{-9}$ mbar. The photoelectron take-off angle (TOA) was normal to the surface of the samples. The sample surface covered by the analysis is $2 \times 5 \mathrm{~mm}^{2}$. Spectra processing (atomic concentrations, curve fitting, etc.) was done after the removal of a Shirley type background with the CasaXPS software. Samples were introduced in the spectrometer readily after plasma treatment in order to limit contamination from ambient air storage and directly analysed.

\section{RESULTS AND DISCUSSION}

\section{Optical emission spectroscopy}

The $\mathrm{Ar}-\mathrm{O}_{2}$ afterglow, run in the continuous mode, was characterized with and without APTES by OES (figure 2). Observed transitions are reported in Table 1. Without APTES, the 
visible light from the afterglow is very weak and only visible in the dark with the naked eye. Besides a non-negligible contribution due to the $\mathrm{OH}\left(A^{2} \Sigma^{+}, v^{\prime}=0 \rightarrow X^{2} \Pi, v^{\prime \prime}=0\right)$ at $306 \mathrm{~nm}$, the green line of atomic oxygen at $557.7 \mathrm{~nm}$ due to the $\mathrm{O}\left({ }^{1} \mathrm{~S} \rightarrow{ }^{1} \mathrm{D}\right)$ transition, called the green line and the atmospheric band of $\mathrm{O}_{2}$ due to the $\mathrm{O}_{2}\left(b^{1} \Sigma_{g}^{+} \rightarrow X^{3} \Sigma_{g}^{-}\right)$transition at $762 \mathrm{~nm}$ could be also recorded with the highest iCCD gain (the $\mathrm{OH}$ emission saturates in these conditions - see supplemental material 1). Indeed, the two latter transitions arise from metastable states produced by the following mechanism:

$$
\begin{gathered}
\mathrm{O}+\mathrm{O}+\mathrm{O} \rightarrow \mathrm{O}\left({ }^{1} \mathrm{~S}\right)+\mathrm{O}_{2} \\
\mathrm{O}+\mathrm{O}+\mathrm{M} \rightarrow \mathrm{O}_{2}\left(b^{1} \Sigma_{g}^{+}\right)+\mathrm{M}
\end{gathered}
$$

and are then very weak in intensity. Light being recorded with an optical fiber, concentrations are determined with respect to its position (defined within two mm typically), regardless of the spatial gradients that extend over much larger distances (several tens of $\mathrm{cm}$ ).

To determine the concentration of oxygen atoms, the NO-titration method was applied. This is a two-step method described in ref. [23]: In a first step, optical calibration is performed by mixing an $\mathrm{Ar}-\mathrm{N}_{2}$ afterglow and a $\mathrm{Ar}-1.4 \mathrm{vol} . \% \mathrm{NO}$ mixture introduced instead of the $\mathrm{Ar}-$ APTES mixture (point B in figure 1). The same arrangement is introduced in a second step to determine the concentration of oxygen atoms at the mixing point of the Ar- $1.4 \mathrm{vol} . \% \mathrm{NO}$ mixture with the $\mathrm{Ar}-\mathrm{O}_{2}$ afterglow (point $\mathrm{B}$ in figure 1). This method leads to [O] = $5.4 \pm 1.0 \times 10^{15} \mathrm{~cm}^{-3}$

Thanks to this value, the absolute concentrations of all emitting species, provided they are intense enough, could be determined with an accuracy of about $30 \%$. Thus, the concentration of the $\mathrm{O}_{2}\left(b^{1} \Sigma_{g}^{+}, v^{\prime}=0\right)$ emitting states leading to the atmospheric band could be determined: $\left[\mathrm{O}_{2}\left(b^{1} \Sigma_{g}^{+}, v^{\prime}=0\right)\right]=5.1 \pm 2.0 \times 10^{11} \mathrm{~cm}^{-3}$. This value is consistent with the $\mathrm{O}$ atom 
concentration reported previously. Indeed, these two concentrations are connected through process (b). To determine the $\mathrm{O}$ atom concentration from the $\mathrm{O}_{2}\left(b^{1} \Sigma_{g}^{+}, v^{\prime}=0\right)$ state, we used the model presented in [24]. It gives $[\mathrm{O}]=3.2 \pm 1.0 \times 10^{15} \mathrm{~cm}^{-3}$. We found $[\mathrm{CH}(\mathrm{A})]=$ $9.2 \pm 3.0 \times 10^{6} \mathrm{~cm}^{-3},[\mathrm{CN}(\mathrm{B})]=2.6 \pm 0.8 \times 10^{5} \mathrm{~cm}^{-3}$ and $[\mathrm{OH}(\mathrm{A})]=2.0 \pm 0.5 \times 10^{8} \mathrm{~cm}^{-3}$ when the afterglow is run in the continuous mode. The rotational spectrum of the atmospheric band was used to determine the gas temperature (as supplemental material 2). A temperature of $330 \pm 5$ $\mathrm{K}$ was found, confirming the low temperature of the afterglow.

When APTES is added to the afterglow, new transitions are observed. They are listed in Table 1. Besides $\mathrm{OH}$ emission which increases strongly (by about one order of magnitude), emissions of non-oxidized molecules, $\mathrm{CH}$ and $\mathrm{CN}$, are found (see high-resolution spectra provided as supplemental material 3). The green line and the atmospheric band are no longer visible in these conditions.

$\mathrm{CH}$ comes naturally from APTES. The origin of the chimiluminescence band of $\mathrm{CH}(A)$ was clarified by Devriendt et al. [25] after the reference work by Grebe et al. [26]. It would be due to the following reaction:

$$
\mathrm{O}+\mathrm{C}_{2} \mathrm{H}\left(X^{2} \Sigma_{g}^{+}\right) \rightarrow \mathrm{CH}\left(A^{2} \Delta_{g}\right)+\mathrm{CO}
$$

with $k_{c}=1.1 \times 10^{-11} \mathrm{~cm}^{3} \mathrm{~s}^{-1}$ at $300 \mathrm{~K}$ and

$$
\mathrm{O}_{2}+\mathrm{C}_{2} \mathrm{H}\left(X^{2} \Sigma_{g}^{+}\right) \rightarrow \mathrm{CH}\left(A^{2} \Delta_{g}\right)+\mathrm{CO}_{2}
$$

with $k_{d}=3.6 \times 10^{-14} \mathrm{~cm}^{3} \mathrm{~s}^{-1}$ at $290 \mathrm{~K}$ [27]. A less probable origin of $\mathrm{CH}(A)$ is [28]:

$$
\mathrm{C}_{2}+\mathrm{OH} \rightarrow \mathrm{CH}\left(A^{2} \Delta_{g}\right)+\mathrm{CO}
$$

because no emission of the Swan system due to $C_{2}$ excited states is observed in our conditions, contrary to data reported in [27]. 
Kinetics of $\mathrm{CH}(A)$ - only the ground state is considered here - is associated with the following spontaneous emission and quenching processes:

$$
\begin{gathered}
\mathrm{CH}\left(A^{2} \Delta_{g}\right) \rightarrow \mathrm{CH}\left(X^{2} \Pi_{u}\right)+\mathrm{h} v \\
\mathrm{CH}\left(A^{2} \Delta_{g}\right)+\mathrm{M} \rightarrow \mathrm{CH}\left(X^{2} \Pi_{u}\right)+\mathrm{M}
\end{gathered}
$$

The radiative lifetime of $\mathrm{CH}(\mathrm{A})$ is $540 \mathrm{~ns}$ [28]. The quenching rates by $\mathrm{Ar}$ and $\mathrm{O}_{2}$ are given by Chen et al. [29]: $k_{g}^{A r}=5.2 \times 10^{-13} \mathrm{~cm}^{3} \mathrm{~s}^{-1}$ et $k_{g}^{O_{2}}=2.2 \times 10^{-11} \mathrm{~cm}^{3} \mathrm{~s}^{-1}$. Applying the quasisteady state approximation (processes c, d, f and g), one finds:

$$
\left[\mathrm{C}_{2} \mathrm{H}\right]=\frac{\left(k_{g}^{A r}[\mathrm{Ar}]+k_{g}^{O_{2}}\left[\mathrm{O}_{2}\right]+\tau_{C H(A)}^{-1}\right)[\mathrm{CH}(A)]}{k_{c}[\mathrm{O}]+k_{d}\left[\mathrm{O}_{2}\right]}
$$

This leads to $\left[\mathrm{C}_{2} \mathrm{H}\right]=1.3 \pm 3.0 \times 10^{8} \mathrm{~cm}^{-3}$. The APTES concentration being $3.9 \times 10^{13} \mathrm{~cm}^{-3}$, the production of $\mathrm{C}_{2} \mathrm{H}$ radicals is a negligible reaction pathway.

The presence of $\mathrm{CN}$ molecules is necessarily due to the nitrogen atom present in the amine group and to one carbon atom coming from the precursor, but not mandatorily the one attached to amine group. To the best of our knowledge, the only mechanism accounting for the emission of the $\mathrm{CN}$ violet system in an argon-oxygen afterglow is [30]:

$$
\mathrm{O}+\mathrm{O}+\mathrm{CN}(X) \rightarrow \mathrm{O}_{2}+\mathrm{CN}(B)
$$

Indeed, the reaction of $\mathrm{N}$ with $\mathrm{CH}$ for example, or with $\mathrm{C}$ and a third body is highly unlikely, nitrogen atoms being not present as such in oxygen afterglows. The rate constant of process (h) is given with a high uncertainty: $k_{h}=(3-30) \times 10^{-31} \mathrm{~cm}^{6} \mathrm{~s}^{-1}[30]$.

The loss mechanisms of the $\mathrm{CN}(\mathrm{B})$ state are the following spontaneous emission and quenching processes:

$$
\begin{gathered}
\mathrm{CN}(B) \rightarrow \mathrm{CN}(X)+\mathrm{h} v \\
\mathrm{CN}(B)+\mathrm{M} \rightarrow \mathrm{CN}(X)+\mathrm{M}
\end{gathered}
$$


The radiative lifetime of $\mathrm{CN}(\mathrm{B}, v=0)$ is $\tau_{\mathrm{CN}(\mathrm{B})}=66.6 \mathrm{~ns}$ [31]. The quenching rate by Ar is given by [32]: $\quad k_{j}^{A r}=1.0 \times 10^{-11} \mathrm{~cm}^{3} \mathrm{~s}^{-1}$. For $\mathrm{O}_{2}$, we took the same value as $\mathrm{N}_{2}$ [32]: $k_{j}^{O_{2}}=2.5 \times 10^{-11} \mathrm{~cm}^{3} \mathrm{~s}^{-1}$.

Applying the quasi-steady state approximation (processes $\mathrm{h}, \mathrm{i}$ and $\mathrm{j}$ ), one finds:

$$
[\mathrm{CN}]=\frac{\left(k_{j}^{A r}[\mathrm{Ar}]+k_{j}^{O_{2}}\left[\mathrm{O}_{2}\right]+\tau_{\mathrm{CN}(\mathrm{B})}^{-1}\right)[\mathrm{CN}(B)]}{k_{h}[\mathrm{O}]^{2}}
$$

This gives: $[\mathrm{CN}]=(0.56$ or 5.6$) \times 10^{11} \mathrm{~cm}^{-3}$, according to the chosen value of $k_{h}$, which is at best a hundredth of the APTES concentration. Then, the production of $\mathrm{CN}$ radicals is a minor reaction pathway.

The origin of the $\mathrm{OH}$ chimiluminescence is well-known from works on acetylene combustion. It is due to the following excitation process:

$$
\mathrm{O}_{2}+\mathrm{CH}(\mathrm{X}) \rightarrow \mathrm{OH}(\mathrm{A})+\mathrm{CO}
$$

Carl et al. [33] give for a temperature in the range [296-511] K:

$$
k_{k}=1.06 \times 10^{-13} \exp \left(-\frac{84}{T(K)}\right)
$$

i.e. at $300 \mathrm{~K}, k_{k}=8.0 \times 10^{-14} \mathrm{~cm}^{3} \mathrm{~s}^{-1}$. The loss mechanisms of $\mathrm{OH}(\mathrm{A})$ are the following spontaneous emission and quenching processes:

$$
\begin{gathered}
\mathrm{OH}(\mathrm{A})+\mathrm{M} \rightarrow \mathrm{OH}+\mathrm{M} \\
\mathrm{OH}(\mathrm{A}) \rightarrow \mathrm{OH}
\end{gathered}
$$

where $\mathrm{M}=\mathrm{Ar}$ or $\mathrm{O}_{2}$. The rate constants of the quenching processes by these species are respectively $k_{l}^{A r}=8.8 \times 10^{-14} \mathrm{~cm}^{3} \mathrm{~s}^{-1}$ [34] and $k_{l}^{O_{2}}=8.0 \times 10^{-11} \mathrm{~cm}^{3} \mathrm{~s}^{-1}$ [35]. For spontaneous emission, we consider only the $v^{\prime}=0$ level with $\tau_{\mathrm{OH}(\mathrm{A})}=800 \mathrm{~ns}[34]$.

Applying the quasi-steady state approximation (processes $\mathrm{k}, \mathrm{l}$ and $\mathrm{m}$ ), one finds: 


$$
[\mathrm{CH}]=\frac{\left(k_{l}^{A r}[\mathrm{Ar}]+k_{l}^{O_{2}}\left[\mathrm{O}_{2}\right]+\tau_{\mathrm{OH}(\mathrm{A})}^{-1}\right)[\mathrm{OH}(A)]}{k_{k}\left[\mathrm{O}_{2}\right]}
$$

This gives: $[\mathrm{CH}]=3.0 \times 10^{11} \mathrm{~cm}^{-3}$, which is also a hundredth of the APTES concentration. Then, the production of $\mathrm{CH}$ radicals can also be considered as a minor reaction pathway.

\section{FTIR spectroscopy}

FTIR measurements were performed in the range $\left[500-4000 \mathrm{~cm}^{-1}\right]$ without and with APTES (Figure 3). In table 2, the functional groups in gaseous APTES were identified by comparison of FTIR data with those reported in the literature [36-47].

The absorption band at $785 \mathrm{~cm}^{-1}$ corresponds to $\mathrm{NH}_{2}$ wagging [38]. This mode has been further confirmed by isotope exchange studies where a red shift of $145 \mathrm{~cm}^{-1}$ was observed for the $\mathrm{ND}_{2}$ wagging mode [38]. This assignment is particularly important because, together with the shoulder at $2745 \mathrm{~cm}^{-1}$ which is attributed by White and Tripp [40] to $\mathrm{Si}-\mathrm{OH} . . . \mathrm{NH}_{2}$, these peaks are the only way to follow the $\mathrm{NH}_{2}$ group through reaction processes. Indeed, other bands like $\mathrm{v}_{\mathrm{s}}(\mathrm{N}-\mathrm{H})$ around 3305 and $3350 \mathrm{~cm}^{-1}$ are not detected in our case. The absorption band at $1615 \mathrm{~cm}^{-1}$ represents the bending vibration of aliphatic amine $(\mathrm{N}-\mathrm{H})$ groups [39] but it is extremely weak and this absorption band cannot be kept to follow the evolution of the $\mathrm{NH}_{2}$ group in the APTES molecule. It is also true for the band at $3219 \mathrm{~cm}^{-1}$ which is due to $\mathrm{CH}_{2}-\mathrm{NH}_{2}$ [36]. The band at $785 \mathrm{~cm}^{-1}$ is higher (typically a tenth of the peak at $1065 \mathrm{~cm}^{-1}$, for instance) and characterized by a broad profile.

The band at $878 \mathrm{~cm}^{-1}$ is due to $\mathrm{CH}_{3}$ rocking mode [42]. Si-O-C, Si-O in APTES and $\mathrm{Si}-\mathrm{O}-$ $\mathrm{C}_{2} \mathrm{H}_{5}$ contribute to bands centred at 1110,1065 and $958 \mathrm{~cm}^{-1}$ [40, 42, 47, 48]. $\mathrm{CH}_{2}$ rocking is observed at $1176 \mathrm{~cm}^{-1}[41,42]$ whereas $\mathrm{H}-\mathrm{C}-\mathrm{H}$ bending is characterized by bands at 1475 and $1449 \mathrm{~cm}^{-1}[36,43]$. The absorption band at $1241 \mathrm{~cm}^{-1}$ corresponds to the asymmetric stretching of $\mathrm{SiO}-\mathrm{CH}_{2}$ [42]. $\mathrm{CH}_{2}$ bending is observed at $1391 \mathrm{~cm}^{-1}$ and corresponds to a $\mathrm{CH}_{2}$ 
group distant from Si [38, 39]. Si-O overtones are visible at 2264 and $2116 \mathrm{~cm}^{-1}$ [45]. Combinations bands centred at $1938 \mathrm{~cm}^{-1}$ are due to $\mathrm{Si}-\mathrm{O}$ and $\rho \mathrm{CH}_{3}$ [44]. Vibrations at 2987 $\mathrm{cm}^{-1}, 2939 \mathrm{~cm}^{-1}, 2899 \mathrm{~cm}^{-1}$ and $2870 \mathrm{~cm}^{-1}$ are commonly assigned to symmetric and asymmetric stretching of $\mathrm{CH}_{2}$ and $\mathrm{CH}_{3}[41,45]$. Finally, the absorption band at $3674 \mathrm{~cm}^{-1}$ is assigned to free $\mathrm{OH}$ [45], which is likely present because of some ageing of the precursor.

When the plasma is turned on, new contributions appear (figure 3). A very broad band centred at $3234 \mathrm{~cm}^{-1}$ spans from 3050 to $3550 \mathrm{~cm}^{-1}$. It is attributed to normal "polymeric" $\mathrm{OH}$ stretch $(>\mathrm{C}=\mathrm{O} \cdots \mathrm{H}-\mathrm{O})[45,47]$. Absorption bands at $2140 \mathrm{~cm}^{-1}$ and $1744 \mathrm{~cm}^{-1}$ are attributed to $\mathrm{CO}$ molecules and $\mathrm{C}=\mathrm{O}$ stretching respectively [42]. At $2348 \mathrm{~cm}^{-1}$, the characteristic absorption of $\mathrm{CO}_{2}$ is easily identified. The contribution at $667 \mathrm{~cm}^{-1}$ is clearly due to $\delta \mathrm{CO}_{2}$ [46].

The interaction of the APTES with the Ar- $\mathrm{O}_{2}$ afterglow is characterized by the formation of ketones resulting from the interaction of oxygen with carbon atoms of the precursor and the synthesis of $\mathrm{CO}$ and $\mathrm{CO}_{2}$ as gaseous by-products. In the present conditions, the APTES concentration is roughly divided by a factor of 3 in afterglow when the plasma is ignited. It is also true for the amine group.

\section{Evolutions in pulse mode}

In pulse mode, it is possible to follow the time-resolved emission of emitting species. In figure 4, the time evolutions of $\mathrm{CH}, \mathrm{CN}$ and $\mathrm{OH}$ normalized transitions together with the control pulse are depicted. After plasma ignition, active species are transported downstream to react with APTES. The delay of $\sim 20 \mathrm{~ms}$ observed before emissive species start rising is caused by this transfer step. Next, a steady state is reached within $10 \mathrm{~ms}$, leading to a plateau in emission. When the plasma is turned off, an overshoot in intensity is clearly visible for all species. This phenomenon is attributed to a sudden pressure variation. When the plasma stops, the gas is no longer heated, which leads to a pressure rise until pumping overcomes this 
effect. The intensity of the overshoot is all the more reduced as the pressure decreases (unreported results), which supports this assumption. Taking the value of the intensity of each transition $50 \mathrm{~ms}$ after the rising edge of the pulse, i.e. in the middle of the plateau, we observe the behaviour described in figure 5 as a function of the duty cycle. Transition intensities evolve similarly, increasing first up to $\mathrm{DC}=40-50 \%$, reaching next a maximum from $\mathrm{DC}=40$ 50 to 60 , and slightly decreasing beyond $\mathrm{DC}=60 \%$.

FTIR absorption spectra were recorded as a function of the duty cycle. In figure 6 , the most intense absorption bands are reported (see Supplemental material $\mathbf{4}$ for details). The $\mathrm{CH}$ absorption band that characterizes the non-oxidized APTES molecule decreases when the duty cycle increases. Oxidation of organosilicon compound is known to follow such a trend, the increase in the duty cycle leading to higher oxidation level and to a transition from plasma polymer to inorganic material [48-50]. Here, the transition occurs near DC $=60 \%$, in agreement with results obtained by time-resolved emission spectroscopy.

\section{Nanoparticles synthesis}

Thin film deposition on the reactor wall is a relatively slow process in the present condition because of the low partial pressure of the precursor. The deposition rate is about $150 \mathrm{ng} \mathrm{mm}^{-2}$ $\min ^{-1}$ and then, no significant drift of the afterglow parameters is observed if the inner wall of the tube is cleaned between successive experiments. A thorough description of thin film deposition will be provided in a forthcoming publication. Here, emphasis is placed on the synthesis of nanoparticles in the gas phase. The process is about one order of magnitude slower than thin film deposition and strongly dependant on the duty cycle. After a two-hour treatment, nanoparticles collected on an aluminium substrate were analysed by scanning electron microscopy, transmission electron microscopy and FTIR absorption spectroscopy. In figure 7, SEM images of micrometric powders made of agglomerates of primary nanoparticles are depicted for two duty cycles: $20 \%$ and $70 \%$. We notice that nanoparticles collected at low 
duty cycle exhibit a highly-porous structure contrary to those collected at high duty cycle, which look like denser. Corresponding TEM images show however similar features: agglomerates have diameters of $\sim 200 \mathrm{~nm}$ and are made of an assembly of amorphous nanoparticles with diameters of a few nanometres. These results are quite similar to those presented by Roth et al. with other organosilicon precursors [51].

FTIR analysis of nanoparticles shows also strong changes in absorption bands (figure 8 and table 3) as a function of the duty cycle. We observe in figure 9, that FTIR absorbance spectra of the nanoparticles exhibit similar features with decaying intensity when the duty cycle increases - see supplemental material 5 for a deconvolution of the bands between 1800 and $800 \mathrm{~cm}^{-1}-$. First, the $\mathrm{Si}-\mathrm{O}-\mathrm{C}_{2} \mathrm{H}_{5}$ absorption band in APTES appears at $950 \mathrm{~cm}^{-1}$. It is a footprint of the precursor together with bands at 1169 and $1083 \mathrm{~cm}^{-1}$ designated hereafter as "Si-O in APTES" [42]. At $1376 \mathrm{~cm}^{-1}, \delta \mathrm{CH}_{2}$ bonds are likely. The contribution at $1441 \mathrm{~cm}^{-1}$, is assigned to $\delta \mathrm{C}-\mathrm{O}-\mathrm{H}$. $\delta \mathrm{NH}_{2}$ (the amide II band) in primary amides appears as a shoulder at $1620 \mathrm{~cm}^{-1}$ of the peak at $1698 \mathrm{~cm}^{-1}$ [46]. The contribution at $1698 \mathrm{~cm}^{-1}$ is attributed to $\mathrm{CO}$ (amide I band) vibration, but not to pure ketones commonly found at $1730 \mathrm{~cm}^{-1}$ [46]. Vibrations at $2930 \mathrm{~cm}^{-1}$ and $2870 \mathrm{~cm}^{-1}$ are convolutions of respectively symmetric and asymmetric stretching of $\mathrm{CH}_{2}$ and $\mathrm{CH}_{3}[41,45]$. The absorption band with its maximum at $3250 \mathrm{~cm}^{-1}$ and spanning over the range $\left[3120-3350 \mathrm{~cm}^{-1}\right.$ ] is assigned to $v_{\mathrm{s}}$ and $\mathrm{v}_{\mathrm{as}} \mathrm{NH}_{2}$. Indeed, primary amides display two strong $\mathrm{NH}_{2}$ stretching bands, i.e. asymmetric stretching at $3360-3340 \mathrm{~cm}^{-1}$ and symmetric stretching at $3190-3170 \mathrm{~cm}^{-1}$ [42]. Finally, the other very broad band centred at $3500 \mathrm{~cm}^{-1}$ spans from 3350 to $3680 \mathrm{~cm}^{-1}$ is attributed to $\mathrm{OH}$ stretch [42]. EDX analyses of the powders (see supplemental material 6) confirm the presence of nitrogen at low duty cycle.

The striking feature is the change in the nanoparticle composition as the duty cycle increases. The carbon content becomes weaker but non-negligible, even at $\mathrm{DC}=70 \%$ (see supplemental 
material 6) compared to $20 \%$, leading to nanoparticles principally made of $\mathrm{Si}-\mathrm{O}-\mathrm{C}$ chains. XPS spectra confirm this trend (figure 10). We clearly observe the presence of nitrogen, even though the signal becomes noisy beyond DC=50\%. N-C bonds (contribution at $400.1 \mathrm{eV}$ ) dominate but nitrogen can be also slightly oxidized (weaker contribution at $402.0 \mathrm{eV}$ ). Si-O$\mathrm{C}$ chains are mainly found at $101.9 \mathrm{eV}$, the silica-like form of silica appearing as a shoulder at $103.6 \mathrm{eV}$. The $\mathrm{O}(1 \mathrm{~s})$ signal is interpreted accordingly as being the sum of 3 different peaks: $\mathrm{C}=\mathrm{O}$ at $533.1 \mathrm{eV}, \mathrm{O}-\mathrm{H}$ at $531.8 \mathrm{eV}$ and $\mathrm{O}-\mathrm{Si}$ at $530.3 \mathrm{eV}$. Concerning the $\mathrm{C}(1 \mathrm{~s})$ signal, it is worth mentioning here that no significant $\mathrm{C}=\mathrm{O}$ contribution, expected around $287 \mathrm{eV}$, was found. This fourth contribution could have been enforced, but this would have led to a minor peak. Besides, the relatively broad contribution at $288.7 \mathrm{eV}$ likely contains a mixture of O$\mathrm{C}=\mathrm{O}$ and $\mathrm{N}-\mathrm{C}=\mathrm{O}$ contributions. $\mathrm{C}-\mathrm{O}$ and $\mathrm{C}-(\mathrm{C}, \mathrm{H})$ bonds are associated with peaks at 285.6 and $284.6 \mathrm{eV}$ respectively. So, all in all, XPS data confirm well FTIR results.

The longer oxidation process of APTES leads to an inorganic material instead of a plasma polymer-like material, a feature that is common to most organosilicon compounds. FTIR spectra show that the $\mathrm{C}-\mathrm{O}-\mathrm{H}$ and $\mathrm{Si}-\mathrm{O}-\mathrm{C}$ absorption bands at 1441 and $950 \mathrm{~cm}^{-1}$ respectively are still present, but the main $\mathrm{Si}-\mathrm{O}$ contributions at 1169 and $1083 \mathrm{~cm}^{-1}$ are barely observed. Obviously, the $\mathrm{C}-\mathrm{Si} \equiv \mathrm{O}_{3}$ environment, present in APTES, is strongly affected by the duty cycle increase. Concerning the band at $950 \mathrm{~cm}^{-1}$, we cannot exclude a contribution of $\mathrm{Si}-\mathrm{OH}$. However, it should be accompanied by the presence of the $\mathrm{OH}$ vibration band at $3500 \mathrm{~cm}^{-1}$, which is not observed. So, this contribution is certainly minor. No intense contribution is found in the range $[1000-1200] \mathrm{cm}^{-1}$ in the present conditions, showing that nanoparticles are not silica-like.

To sum up, the synthesized nanoparticles are amorphous. They have a plasma polymer-like structure with a silicon backbone and a high amount of amide groups at low duty cycle. At high duty cycle, the nanoparticles still contain some carbon and are not silica-like. 


\section{Mechanisms at stake}

As described previously, the synthesis of $\mathrm{C}_{2} \mathrm{H}, \mathrm{CH}$ and $\mathrm{CN}$ radicals is very limited. As no $\mathrm{N}-$ O bond could be observed, the amine group is assumed to be affected to a limited extent by oxygen, which explains the formation of primary amides in the coating especially at low duty cycle.

The initiation step of APTES decomposition is attributed to atomic oxygen. To the best of our knowledge, contrary to $\mathrm{O}$ atoms [52-55], the singlet state $\mathrm{O}_{2}\left(\mathrm{a}^{1} \Delta_{\mathrm{g}}\right)$ has never been identified as a reactive species with regards to dehydrogenation of organosilicon compounds. Afterglow studies with TEOS [52-54] and HMDSO [48, 53] all reinforce this conclusion.

Wrobel et al. [52] showed, in the case of a remote oxygen Plasma-CVD process, that the growth rate of silica film from TEOS is proportional to the concentration of atomic oxygen. The abstraction of the hydrogen atom from the TEOS molecule is a major reaction to the precursor decomposition. The value of the overall kinetic constant of oxygen atoms with TEOS molecules $k_{\mathrm{O}}$ at room temperature strongly differs according to the authors. $k_{\mathrm{O}}$ was reported to be equal to $6 \times 10^{-15} \mathrm{~cm}^{3} \mathrm{~s}^{-1}$ by [56], $4 \times 10^{-14} \mathrm{~cm}^{3} \mathrm{~s}^{-1}$ by Janča et al. [53] and $4 \times 10^{-13} \mathrm{~cm}^{3} \mathrm{~s}^{-1}$ by Sanogo and Zachariah [57]. So, these values are not helpful to evaluate the reactivity of oxygen atoms with respect to TEOS, a molecule which is relatively similar to APTES. Levedakis et al. [54] used a remote microwave plasma and compared the predicted oxygen atom concentrations with corresponding deposition rates. They found out that the overall $\mathrm{SiO}_{2}$ deposition reaction is largely controlled by the concentration of oxygen atoms. Finally, Georg et al. [55] proposed that a major reason for thin films improvement of roughness and homogeneity is the enhanced oxidation of unwanted carbohydrogen compounds in the HMDSO molecules by atomic oxygen.

We infer from the synthesis of $>\mathrm{CO} \ldots \mathrm{OH}$ bonds (figure $3 \mathrm{c}$ ) and the production of $\mathrm{C}=\mathrm{O}$ in the precursor and/or its fragments that after $\mathrm{OH}$ abstraction by $\mathrm{O}$ atoms (process $\mathrm{n}$ ), $\mathrm{O}_{2}$ (in any 
state, including the singlet state in this case) reacts with the as-formed radical to produce a peroxide, whose lability leads to the scission of $\mathrm{C}-\mathrm{C}$ bonds according to a mechanism of the following kind:

$$
\begin{gathered}
\mathrm{O}+-\mathrm{CH}_{2}-\mathrm{CH}_{2}-\rightarrow \dot{\mathrm{OH}}+-\dot{\mathrm{C}} \mathrm{H}-\mathrm{CH}_{2}- \\
\mathrm{O}_{2}+-\dot{\mathrm{C}} \mathrm{H}-\mathrm{CH}_{2}-\rightarrow-\mathrm{C}(\dot{\mathrm{OO}}) \mathrm{H}-\mathrm{CH}_{2}-\rightarrow-\dot{\mathrm{C}}=\mathrm{O}+\mathrm{HO}-\mathrm{CH}_{2}-
\end{gathered}
$$

Further chemical processes between APTES fragments are not accessible without timeresolved FTIR measurements. The description of the processes will require new investigations. Nevertheless, when the duty cycle increases, fragmentation of the precursor increases since oxidation proceeds longer. Then, reactions between shorter silicon radicals, still attached to carbon-containing groups, occur. This leads to a plasma-polymer material characterized by a non-negligible amount of carbon.

The fact that nanoparticles are not silica-like at high duty cycle shows the specificity of chemical reactions in the gas phase with regard to surface processes at the reactor wall. Indeed, we know from other experiments, which are not reported here, that in our conditions silica-like coatings are obtained on the reactor wall at high duty cycle. Carbon etching by oxygen is much more efficient on the growing coating than on the formed nanoparticles. The reason for this is still to be clarified.

\section{CONCLUSION}

The interaction of (3-Aminopropyl)triethoxysilane with a pulse late $\mathrm{Ar}-\mathrm{O}_{2}$ afterglow is characterized by the synthesis of $\mathrm{OH}, \mathrm{CO}$ and $\mathrm{CO}_{2}$ in the gas phase as main by-products. Other minor species like $\mathrm{CH}, \mathrm{CN}$ and $\mathrm{C}_{2} \mathrm{H}$ are also produced. We suggest that $\mathrm{OH}$ radicals are produced in a first step by dehydrogenation of APTES after interaction with oxygen atoms. In 
a second step, the molecule is oxidized by any state of $\mathrm{O}_{2}$, i.e. not only the ground state but also the singlet state of oxygen, for instance. The as-formed peroxides transform into byproducts, break thus the $\mathrm{C}-\mathrm{C}$ bonds in the precursor. If oxidation is limited, thanks to a low duty cycle, fragmentation of the precursor is limited and nanoparticles produced out of them have a composition comparable to the precursor, even though the original $-\mathrm{NH}_{2}$ groups are efficiently converted into amide groups. At high duty cycle, silicon-containing fragments contain also some carbon and react together and produce nanoparticles with a non-silica-like structure at least in our experimental conditions.

It turns out that, in the present condition, a high retention level of amines in the precursor is not possible, even in pulsed conditions. Although afterglows are soft media, the behaviour of oxygen atoms toward APTES is defined once and for all and cannot be adjusted by simply changing the duty cycle. In this sense, pulsed plasmas are likely more suited to this purpose thanks to electronic collisions which should offer a more controllable way to define the dissociation pathway of APTES by acting on the electron energy.

\section{ACKNOWLEDGMENTS}

This work was done within the framework of the Laboratoire International Associé LIPES, a structure supported by the CNRS to whom we convey our deepest gratitude. We wish to thank also the Région Lorraine and the Institut Carnot ICEEL for the grant of M. GUEYE. 


\section{REFERENCES}

1. Lecoq E., Duday D., Bulou S., Frache G., Hilt F., Maurau R., Choquet P. (2013) Plasma Polymerization of APTES to Elaborate Nitrogen Containing Organosilicon Thin Films: Influence of Process Parameters and Discussion About the Growing Mechanisms. Plasma Process Polym 10(3):250-261. doi:10.1002/ppap.201200108

2. Minier M., Salmain M., Yacoubi N., Barbes L., Methivier C., Zanna S., Pradier C. M. (2005) Covalent immobilization of lysozyme on stainless steel. Interface spectroscopic characterization and measurement of enzymatic activity. Langmuir 21(13): 5957-5965. doi:10.1021/la0501278

3. Schröder K., Finke B., Polak M., Lüthen F., Nebe J.B., Rychly J., Bader R., Lukowski G., Walschus U., Schlosser M., Ohl A., Weltmann K.-D. (2010) Gas-discharge plasma-assisted functionalization of titanium implant surfaces. Mater Sci Forum 638642:700-705. doi:10.4028/www.scientific.net/MSF.638-642.700

4. Nebe B., Finke B., Luthen F., Bergemann C., Schroder K., Rychly J., Liefeith K., Ohl A. (2007) Improved initial osteoblast functions on amino-functionalized titanium surfaces. Biomol Eng 24(5):447-454. doi:10.1016/j.bioeng.2007.07.004

5. Borges J. N., Belmonte T., Guillot J., Duday D., Moreno-Couranjou M., Choquet P., Migeon H. N. (2009) Functionalization of Copper Surfaces by Plasma Treatments to Improve Adhesion of Epoxy Resins. Plasma Process Polym. 6(S1):S490-S495. doi: 10.1002/ppap.200931106

6. Friedrich J. F., Mix R., Kuhn G. (2003) Functional groups bearing plasma homo and copolymer layers as adhesion promoters in metal-polymer composites. Surf Coat Technol 174-175, 811-815. doi: 10.1016/S0257-8972(03)00350-5 
7. Jampala S. N., Sarmadi M., Manolache S., Denes F. S. (2008) Surface functionalization by RF plasma deposition of ethylene diamine, acrylonitrile, and acetonitrile. J Appl Polymer Sci 107(3):1686-1695. doi:10.1002/app.27189

8. Kuhn G., Retzko I., Lippitz A., Unger W., Friedrich J. (2001) Homofunctionalized polymer surfaces formed by selective plasma processes. Surf Coat Technol 142144:494-500. doi:10.1016/S0257-8972(01)01056-8

9. Rinsch C. L., Chen X., Panchalingam V., Eberhart R. C., Wang J. H., Timmons R. B. (1996) Pulsed radio frequency plasma polymerization of allyl alcohol: controlled deposition of surface hydroxyl groups. Langmuir 12(12):2995-3002. doi:10.1021/la950685u

10. Stine R., Cole C. L., Ainslie K. M., Mulvaney S. P., Whitman L. J. (2007) Formation of primary amines on silicon nitride surfaces: a direct, plasma-based pathway to functionalization. Langmuir 23(8):4400-4404. doi:10.1021/la0635653

11. Angelini E., d'Agostino R., Fracassi F., Grassini S., Rosalbino F. (2002) Surface analysis of PECVD organosilicon films for corrosion protection of steel substrates. Surf Interface Anal 34(1):155-159. doi:10.1002/sia.1273

12. Fracassi F., d'Agostino R., Palumbo F., Angelini E., Grassini S., Rosalbino F. (2003) Application of plasma deposited organosilicon thin films for the corrosion protection of metals. Surf. Coat. Technol. 174-175:107-111. doi:10.1016/S0257-8972(03)004225

13. Simor M., Fiala A., Kovacik D., Hlidek P., Wypkema A., Kuipers R. (2007) Corrosion protection of a thin aluminium layer deposited on polyester. Surf Coat Technol 201(18):7802-7812. doi:10.1016/j.surfcoat.2007.03.011 
14. Goddard J. M., Hotchkiss J.H. (2007) Polymer surface modification for the attachment of bioactive compounds. Prog. Polym. Sci. 32(7):698-725. doi:10.1016/j.progpolymsci.2007.04.002

15. Witucki G. L. (1993) A silane primer: chemistry and applications of alkoxy silanes. J. Coat. Technol. 65(822):57-60.

16. Jampala S. N., Sarmadi M., Somers E. B., Wong A. C. L., Denes F. S. (2008) Plasmaenhanced synthesis of bactericidal quaternary ammonium thin layers on stainless steel and cellulose surfaces. Langmuir 24(16):8583-8591. doi:10.1021/la800405x

17. Gandhiraman R. P., Gubala V., Nam L. C. H., Volcke C., Doyle C., James B., Daniels S., Williams D. E. (2010) Deposition of chemically reactive and repellent sites on biosensor chips for reduced non-specific binding. Colloids Surf. B Biointerfaces 79(1):270-275. doi:10.1016/j.colsurfb.2010.04.009

18. Gandhiraman R. P., Volcke C., Gubala V., Doyle C., Basabe-Desmonts L., Dotzler C., Toney M. F., Iacono M., Nooney R. I., Daniels S., James B., Williams D. E. (2010) High efficiency amine functionalization of cycloolefin polymer surfaces for biodiagnostics. J. Mater. Chem. 20(20):4116-4127. doi:10.1039/B925737C

19. Gubala V., Gandhiraman R. P., Volcke C., Doyle C., Coyle C., James B., Daniels S., Williams D. E. (2010) Functionalization of cycloolefin polymer surfaces by plasmaenhanced chemical vapour deposition: comprehensive characterization and analysis of the contact surface and the bulk of aminosiloxane coatings. Analyst 135, 1375-1381. doi:10.1039/B924692D

20. Volcke, C., Gandhiraman, R. P., Gubala, V., Raj, J., Cummins, T., Fonder, G., Nooney R.I., Mekhalif Z., Herzog G., Daniels S., Arrigan D.W.M., 2, Cafolla A.A., Williams D.E. (2010) Reactive amine surfaces for biosensor applications, prepared by plasma- 
enhanced chemical vapour modification of polyolefin materials. Biosensors Bioelectron. 25(8):1875-1880. doi:10.1016/j.bios.2009.12.034

21. Volcke C., Gandhiraman R. P., Gubala V., Doyle C., Fonder G., Thiry P. A., Cafolla A. A., James B., Williams D. E. (2010) Plasma functionalization of AFM tips for measurement of chemical interactions. J. Colloid Interface Sci. 348(2):322-328. doi:10.1016/j.jcis.2010.04.042

22. Sakata J., Wada M. (1988) Preparation of ion exchange membranes by plasma polymerization. I. J. Appl. Polym. Sci. 35(4):875-884. doi:10.1002/app.1988.070350403

23. Ricard A., Moisan M., Moreau S. (2001) Determination, through titration with NO, of the concentration of oxygen atoms in the flowing afterglow of $\mathrm{Ar}-\mathrm{O}_{2}$ and $\mathrm{N}_{2}-\mathrm{O}_{2}$ plasmas used for sterilization purposes. J. Phys. D: Appl. Phys. 34(8):1203-1212. doi:10.1088/0022-3727/34/8/311

24. Mafra M., Belmonte T., Poncin-Epaillard F., Maliska A., Cvelbar U. (2009) Treatment of hexatriacontane by $\mathrm{Ar}-\mathrm{O}_{2}$ remote plasma: formation of the active species. Plasma Process. Polym. 6(S1):S198-S203. doi:10.1002/ppap.200932406

25. Devriendt K., Peeters J. (1997) Direct Identification of the $\mathrm{C}_{2} \mathrm{H}\left(\mathrm{X}^{2} \Sigma^{+}\right)+\mathrm{O}\left({ }^{3} \mathrm{P}\right) \rightarrow$ $\mathrm{CH}\left(\mathrm{A}^{2} \Delta\right)+\mathrm{CO}$ Reaction as the Source of the $\mathrm{CH}\left(\mathrm{A}^{2} \Delta \rightarrow \mathrm{X}^{2} \Pi\right)$ Chemiluminescence in $\mathrm{C}_{2} \mathrm{H}_{2} / \mathrm{O} / \mathrm{H}$ Atomic Flames. J. Phys. Chem. A 101(14):2546-2551. doi:10.1021/jp963434i

26. Grebe J., Homann K. H. (1982) Kinetics of the Species $\mathrm{OH}\left(\mathrm{A}^{2} \Sigma^{+}\right), \mathrm{OH}\left(\mathrm{X}^{2} \Pi\right)$ and $\mathrm{CH}$ $\left(\mathrm{X}^{2} \Pi\right)$ in the System $\mathrm{C}_{2} \mathrm{H}_{2} / \mathrm{O} / \mathrm{H}$. Berichte Bunsenges Phys. Chem., 86(7):581-587. doi:10.1002/bbpc.19820860702 
27. Hidaka Y., Kawano H., Suga M. (1982) Additive Effect of $\mathrm{CF}_{3} \mathrm{Cl}$ on an Oxidation Reaction in Shock Waves. I. Study with $\mathrm{H}_{2}-\mathrm{O}_{2}$. Bull. Chem. Soc. Jap. 55(2):351-357. doi:10.1246/bcsj.55.351

28. Elsamra R. M. I., Vranckx S., Carl S. A. (2005) $\mathrm{CH}\left(\mathrm{A}^{2} \Delta\right)$ formation in hydrocarbon Combustion: the temperature dependence of the rate constant of the reaction $\mathrm{C}_{2} \mathrm{H}+\mathrm{O}_{2}$ $\rightarrow \mathrm{CH}\left(\mathrm{A}^{2} \Delta\right)+\mathrm{CO}_{2}$. J. Phys. Chem. A 109(45):10287-10293. doi:10.1021/jp053684b

29. Chen C., Sheng Y., Yu S., Ma X. (1994) Investigation of the collisional quenching of $\mathrm{CH}\left(\mathrm{A}^{2} \Delta\right.$ and $\left.\mathrm{B}^{2} \Sigma^{-}\right)$by $\mathrm{Ar}, \mathrm{O}_{2}, \mathrm{CS}_{2}$, alcohol, and halomethane molecules. J. Chem. Phys. 101(7):5727-5730. doi:10.1063/1.467358

30. Setser D. W., Thrush B. A. (1965) Kinetics of reactions involving CN emission. II. The reaction between oxygen atoms and cyanogen. Proc. R. Soc. Lond. A Math. Phys. Sci., 288(1413):275-291. doi:10.1098/rspa.1965.0218

31. Knowles P. J., Werner H. J., Hay P. J., Cartwright D. C. (1988) The $A^{2} \Pi-X^{2} \Sigma+$ red and $\mathrm{B}^{2} \Sigma^{+}-\mathrm{X}^{2} \Sigma^{+}$violet systems of the $\mathrm{CN}$ radical: Accurate multireference configuration interaction calculations of the radiative transition probabilities. J. Chem. Phys. 89(12):7334-7343. doi:10.1063/1.455264

32. Tereshchenko E. N., Dodonova N. I., Photoprocesses in the gas phase (Fotoprotsessy v gazovoi faze). Leningrad, Izdatel'stvo Leningradskogo Universiteta (Leningradskii Gosudarstvennyi Universitet, Uspekhi Fotoniki, No. 8), 1983, p. 112-145. In Russian., $1,112-145$.

33. Carl S. A., Van Poppel M., J. Peeters (2003) Identification of the $\mathrm{CH}+\mathrm{O}_{2} \rightarrow \mathrm{OH}$ (A) $+\mathrm{CO}$ Reaction as the Source of $\mathrm{OH}(\mathrm{AX})$ Chemiluminescence in $\mathrm{C}_{2} \mathrm{H}_{2} / \mathrm{O} / \mathrm{H} / \mathrm{O}_{2}$ Atomic Flames and Determination of its Absolute Rate Constant over the Range $\mathrm{T}=$ 296 to 511 K. J. Phys. Chem. A 107(50):11001-11007. doi:10.1021/jp035568j 
34. Leblond J. B., Collier F., Hoffbeck F., Cottin P. (1981) Kinetic study of high-pressure Ar-H2O mixtures excited by relativistic electrons. J. Chem. Phys. 74(11):6242-6255. doi:10.1063/1.441015

35. Fairchild P. W., Smith G. P., Crosley D. R. (1983) Collisional quenching of $\mathrm{A}^{2} \Sigma^{+} \mathrm{OH}$ at elevated temperatures. J. Chem. Phys. 79(4):1795-1807. doi:10.1063/1.446025

36. Weigel Ch., Kellner R. (1989) FTIR-ATR-spectroscopic investigation of the silanization of germanium surfaces with 3-aminopropyltriethoxysilane. Fresenius $\mathrm{Z}$. Anal. Chem. 335(7):663-668. doi:10.1007/BF01204067

37. Finocchio E., Macis E., Raiteri R., Busca G. (2007) Adsorption of trimethoxysilane and of 3-mercaptopropyltrimethoxysilane on silica and on silicon wafers from vapor phase: an IR study. Langmuir 23(5):2505-2509. doi:10.1021/la062972b

38. Rai V. R., Agarwal S. (2011) Mechanism of self-catalytic atomic layer deposition of silicon dioxide using 3-aminopropyl triethoxysilane, water, and ozone. Chem. Mater. 23(9):2312-2316. doi:10.1021/cm103052t

39. Rahman I.A., Jafarzadeh M., Sipaut C.S. (2009) Synthesis of organo-functionalized nanosilica via a co-condensation modification using $\gamma$-aminopropyltriethoxysilane (APTES). Ceram. Int., 35(5):1883-1888. doi:10.1016/j.ceramint.2008.10.028

40. White L. D., Tripp C. P. (2000) Reaction of (3-aminopropyl) dimethylethoxysilane with amine catalysts on silica surfaces. J. Colloid Interf. Sci. 232(2):400-407. doi:10.1006/jcis.2000.7224

41. Aissaoui N., Bergaoui L., Landoulsi J., Lambert J.-F., Boujday S. (2012) Silane layers on silicon surfaces: mechanism of interaction, stability, and influence on protein adsorption. Langmuir 28(1), 656-665. doi:10.1021/la2036778

42. Launer P. J. (1987) "Infrared analysis of organosilicon compounds: spectra-structure correlations", Silicone compounds register and review, 100 
43. Okabayashi H., Shimizu I., Nishio E., O'Connor C. J. (1997) Diffuse reflectance infrared Fourier transform spectral study of the interaction of 3aminopropyltriethoxysilane on silica gel. Behavior of amino groups on the surface. Colloid Polym. Sci. 275(8):744-753. doi:10.1007/s003960050143

44. Workman Jr J., Weyer L. (2007) "Practical guide to interpretive near-infrared spectroscopy", edited by CRC press.

45. Coates J. (2000) "Interpretation of infrared spectra, a practical approach", Encyclopedia of analytical chemistry, edited by John Wiley \& Sons Ltd, Chichester.

46. Stuart B. H. (2004) "Infrared Spectroscopy: Fundamentals and Applications", Analytical Techniques in the Science, edited by John Wiley \& Sons Ltd, Chichester.

47. Liakath Ali Khan F., Sivagurunathan P., Asghar J. (2008) FTIR study of hydrogen bonding interactions between alkyl esters and hexanol, p-cresol in carbon tetrachloride. Indian J. Pure Appl. Phys. 46(1):12.

48. Goujon M., Belmonte T., Henrion G. (2004) OES and FTIR diagnostics of $\mathrm{HMDSO} / \mathrm{O}_{2}$ gas mixtures for $\mathrm{SiO}_{\mathrm{x}}$ deposition assisted by RF plasma. Surf. Coat. Technol. 188-189:756-761. doi:10.1016/j.surfcoat.2004.07.048

49. Bousquet A., Cartry G., Granier A. (2007) Investigation of O-atom kinetics in $\mathrm{O}_{2}$, $\mathrm{CO}_{2}, \mathrm{H}_{2} \mathrm{O}$ and $\mathrm{O}_{2} / \mathrm{HMDSO}$ low pressure radiofrequency pulsed plasmas by timeresolved optical emission spectroscopy. Plasma Sources Sci. Technol. 16(3):597-605. doi:10.1088/0963-0252/16/3/020

50. Supiot P., Vivien C., Blary K., Rouessac V. (2011) Organosilicon Polymers Deposition by PECVD and RPECVD on Micropatterned Substrates. Chem. Vap. Depos. 17(10-12):321-326. doi:10.1002/cvde.201106902 
51. Roth C., Oberbossel G., Buitrago E., Heuberger R., Rudolf von Rohr P. (2012) Nanoparticle synthesis and growth in a continuous plasma reactor from organosilicon precursors. Plasma Process. Polym. 9(2):119-134. doi:10.1002/ppap.201100180

52. Wrobel A. M., Walkiewicz-Pietrzykowska A., Hatanaka Y., Wickramanayaka S., Nakanishi Y. (2001) Oligomerization and polymerization steps in remote plasma chemical vapor deposition of silicon-carbon and silica films from organosilicon sources. Chem. Mater. 13(5):1884-1895. doi:10.1021/cm001044+

53. Janča J., Tálský A., Zvoníček V. (1996) Kinetics of $\mathrm{O}_{2}+$ TEOS gas-phase chemical reactions in a remote RF plasma reactor with electron spin resonance. Plasma Chem. Plasma Proc. 16(2):187-194. doi:10.1007/BF01570177

54. Levedakis D. A., Raupp G. B. (1992) "Oxygen Atom Induced Deposition of Silicon Dioxide." MRS Proceedings (Vol. 282, p. 537). Cambridge University Press.

55. Georg A., Engemann J., Brockhaus A. (2002) Investigation of a pulsed oxygen microwave plasma by time-resolved two-photon allowed laser-induced fluorescence. J. Phys. D: Appl. Phys. 35(9):875-881. doi:10.1088/0022-3727/35/9/307

56. Kawahara T., Yuuki A., Matsui Y. (1992) Reaction mechanism of chemical vapor deposition using tetraethylorthosilicate and ozone at atmospheric pressure. Jpn. J. Appl. Phys. 31(9R):2925-2930. doi:10.1143/JJAP.31.2925

57. Sanogo O., Zachariah M. R. (1997) Kinetic studies of the reaction of tetraethoxysilane with oxygen atoms. J. Electrochem. Soc. 144(8):2919-2923. doi:10.1149/1.1837918 


\section{FIGURE CAPTION}

Figure 1: The experimental setup.

Figure 2: Low-resolution optical emission spectra of the $\mathrm{Ar}-\mathrm{O}_{2}$ afterglow with and without APTES.

Figure 3: Gas phase FTIR spectra of the Ar-APTES flow without (red) and with (black) the Ar- $\mathrm{O}_{2}$ afterglow. Resolution: $2 \mathrm{~cm}^{-1}$. a) Infrared region: from 1700 to $500 \mathrm{~cm}^{-1}$. b) Infrared region: from 2600 to $1700 \mathrm{~cm}^{-1}$. The signal obtained with the $\mathrm{Ar}-\mathrm{O}_{2}$ afterglow was divided by a factor of 2 to better scale the figure and show details of the other signal recorded without the afterglow. c) Infrared region: from 4000 to $2600 \mathrm{~cm}^{-1}$.

Figure 4: Time evolution of $\mathrm{CH}, \mathrm{CN}$ and $\mathrm{OH}$ normalized transitions together with the control pulse $($ Duty cycle $=60 \%, \mathrm{P}=15$ mbar, $\mathrm{W}=250 \mathrm{~W}$, plasma gas flowrates: $\mathrm{Ar}=1050 \mathrm{sccm}$, $\mathrm{O}_{2}=100 \mathrm{sccm}$. Precursor flowrates: Ar =30 sccm, APTES = $\left.0.13 \mathrm{sccm}\right)$.

Figure 5: Evolution of $\mathrm{CH}, \mathrm{CN}$ and $\mathrm{OH}$ transitions taken $50 \mathrm{~ms}$ after the pulse rising edge as a function of the duty cycle (same conditions as in figure 4).

Figure 6: Evolution of the most intense FTIR absorption bands as a function of the duty cycle (same conditions as in figure 4).

Figure 7: TEM and SEM images of nanoparticles collected on an aluminium substrate at duty cycles equal to $20 \%$ and $70 \%$.

Figure 8: FTIR spectrum of solid nanoparticles collected in the gas phase at duty cycle equal to $20 \%$. Infrared region: from 3750 to $750 \mathrm{~cm}^{-1}$. Resolution: $2 \mathrm{~cm}^{-1}$.

Figure 9: FTIR spectra of solid nanoparticles collected in the gas phase at different duty cycles (from 20 to $70 \%$ ). Infrared region: from 3750 to $750 \mathrm{~cm}^{-1}$. Resolution: $2 \mathrm{~cm}^{-1}$.

Figure 10: $\mathrm{O}(1 \mathrm{~s}), \mathrm{N}(1 \mathrm{~s}), \mathrm{C}(1 \mathrm{~s})$ and $\mathrm{Si}(2 \mathrm{p})$ XPS spectra of nanoparticles collected on an aluminium substrate for different duty cycles. 
Table 1: List of the transitions observed by optical emission spectroscopy in the $\mathrm{Ar}-\mathrm{O}_{2}$ afterglow with and without APTES.

Table 2: Vibrational groups and their corresponding frequencies observed in the APTES flow with (bold) and without $\mathrm{Ar}-\mathrm{O}_{2}$ afterglow.

Table 3: Main vibrational groups and their corresponding frequencies observed in nanoparticles produced from APTES for different duty cycles (from 20 to 70\%). 


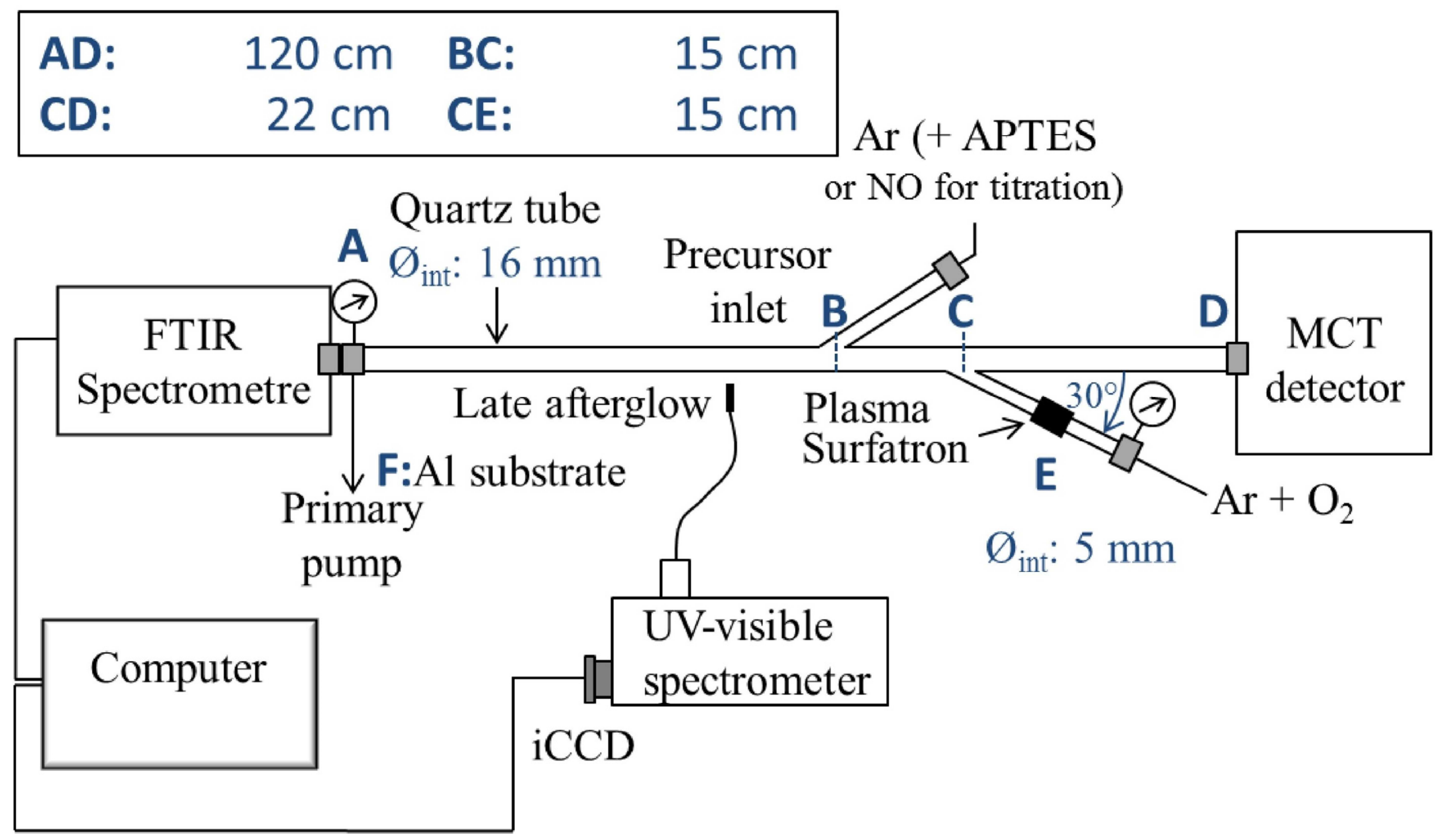

Figure 1: The experimental setup. 


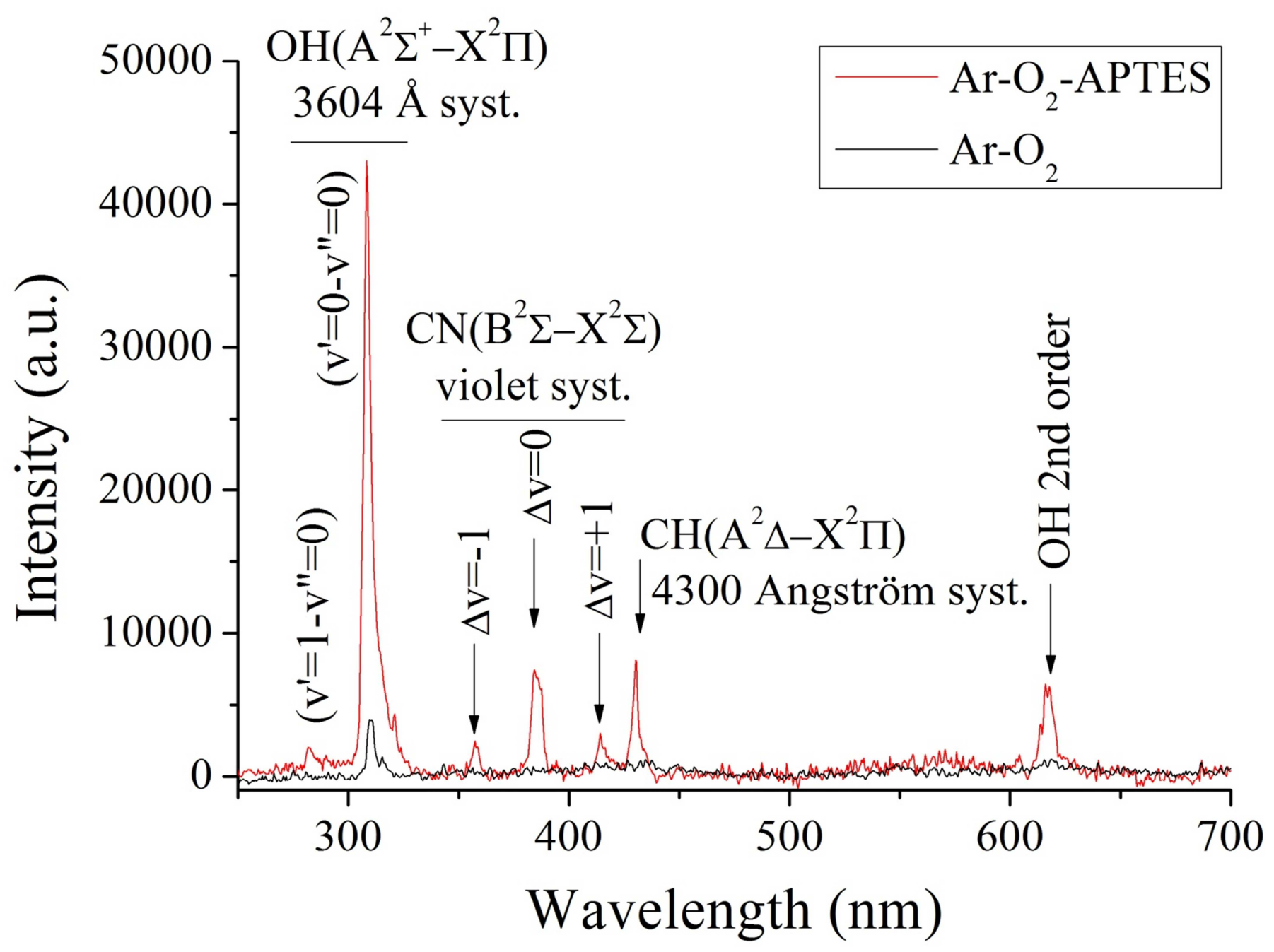

Figure 2: Low-resolution optical emission spectra of the $\mathrm{Ar}-\mathrm{O}_{2}$ afterglow with and without APTES. 


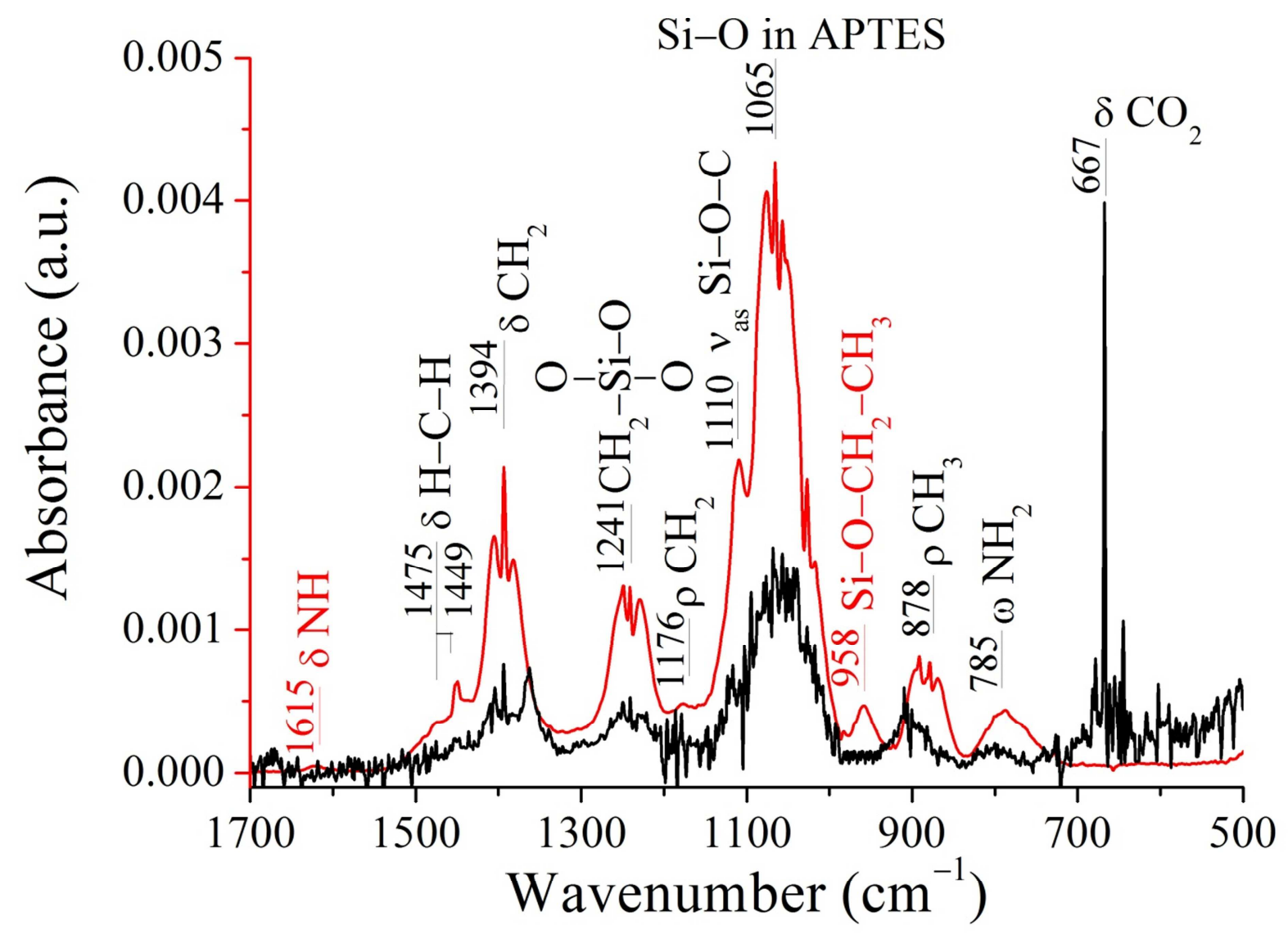

Figure 3a: Gas phase FTIR spectra of the Ar-APTES flow without (red) and with (black) the Ar- $\mathrm{O}_{2}$ afterglow. Resolution: $2 \mathrm{~cm}^{-1}$. a) Infrared region: from 1700 to $500 \mathrm{~cm}^{-1}$. 


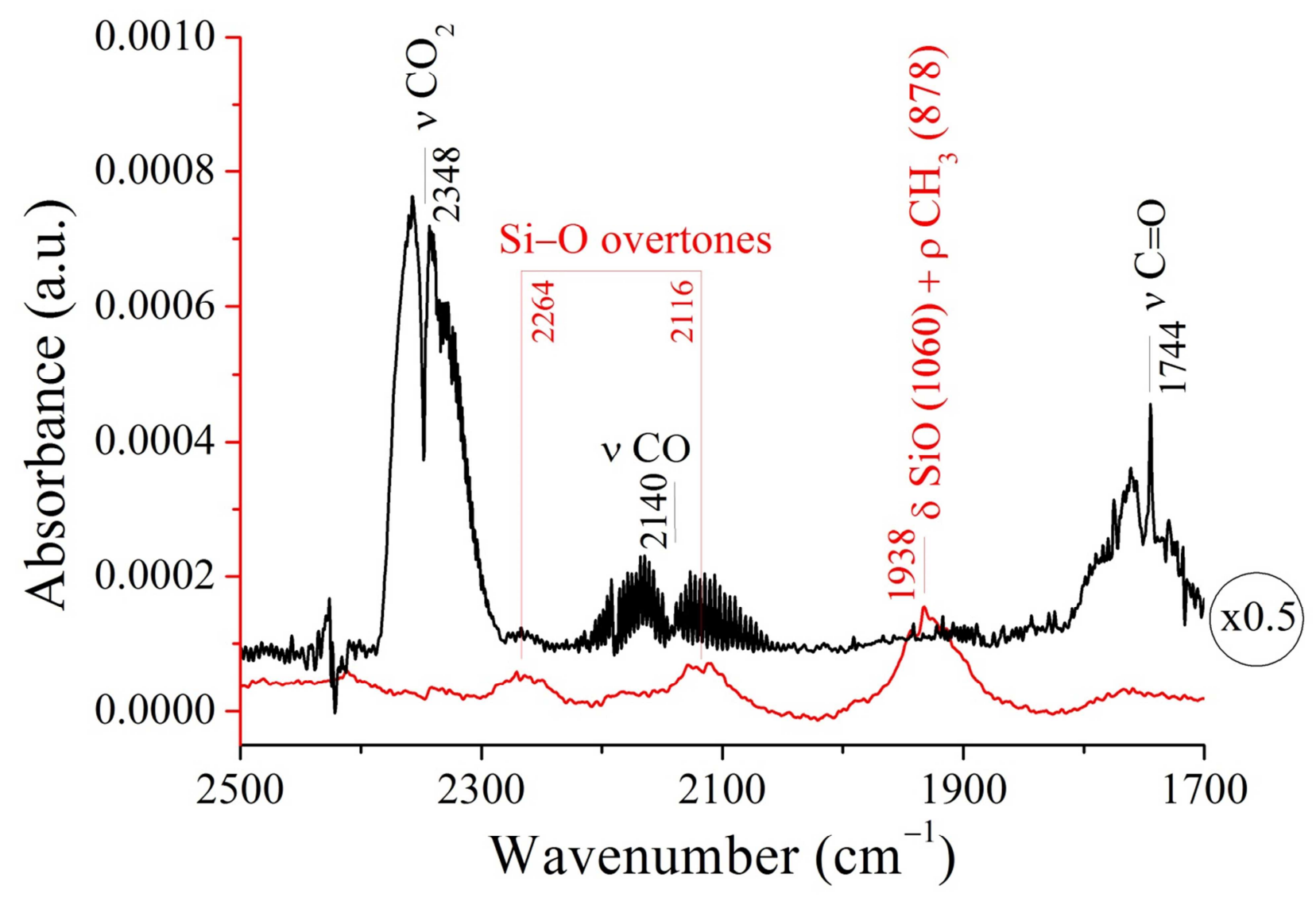

Figure 3b: Gas phase FTIR spectra of the Ar-APTES flow without (red) and with (black) the Ar- $\mathrm{O}_{2}$ afterglow. Resolution: $2 \mathrm{~cm}^{-1}$. b) Infrared region: from 2600 to $1700 \mathrm{~cm}^{-1}$. The signal obtained with the $\mathrm{Ar}-\mathrm{O}_{2}$ afterglow was divided by a factor of 2 to better scale the figure and show details of the other signal recorded without the afterglow. 


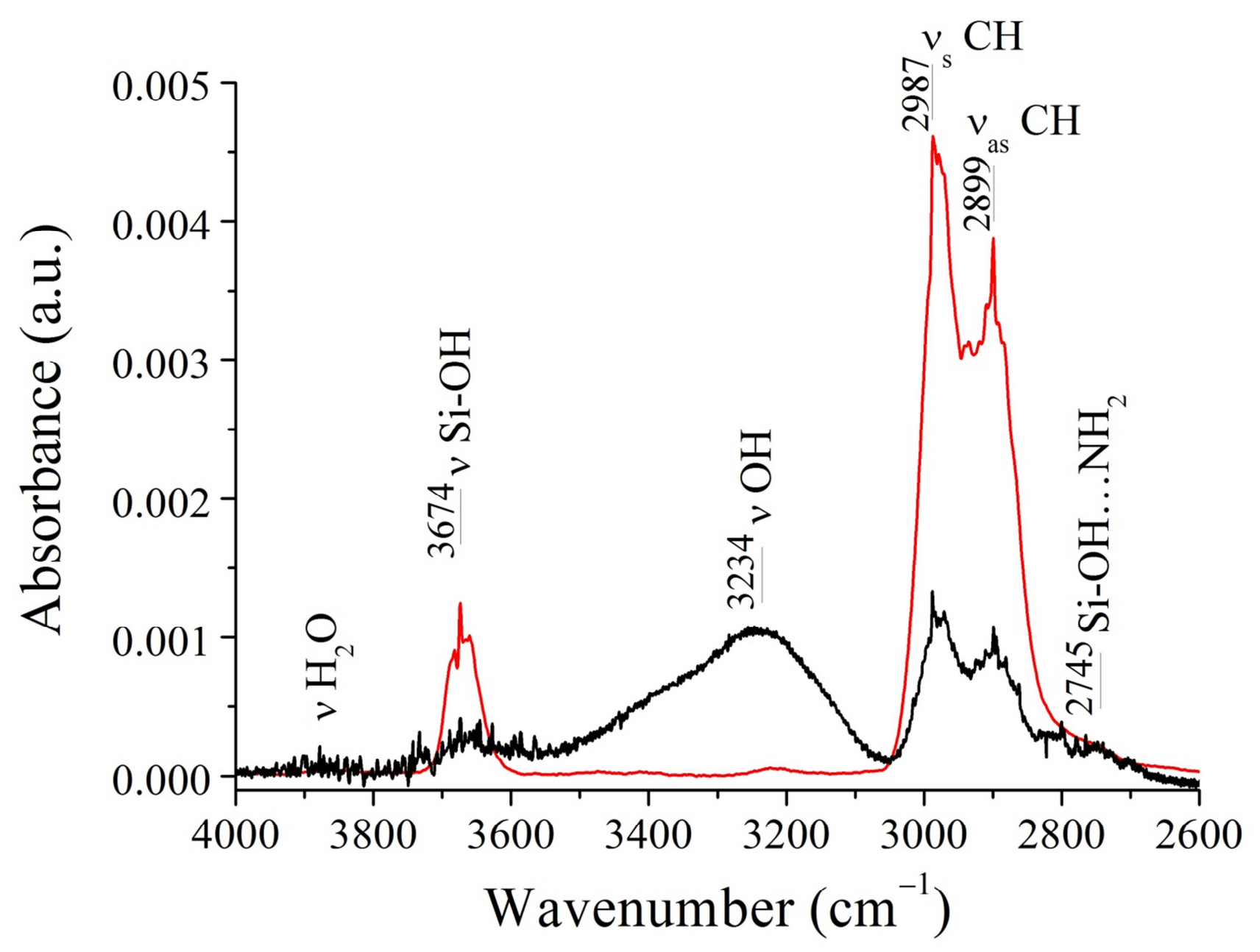

Figure 3c: Gas phase FTIR spectra of the Ar-APTES flow without (red) and with (black) the Ar- $\mathrm{O}_{2}$ afterglow. Resolution: $2 \mathrm{~cm}^{-1}$. c) Infrared region: from 4000 to $2600 \mathrm{~cm}^{-1}$. 


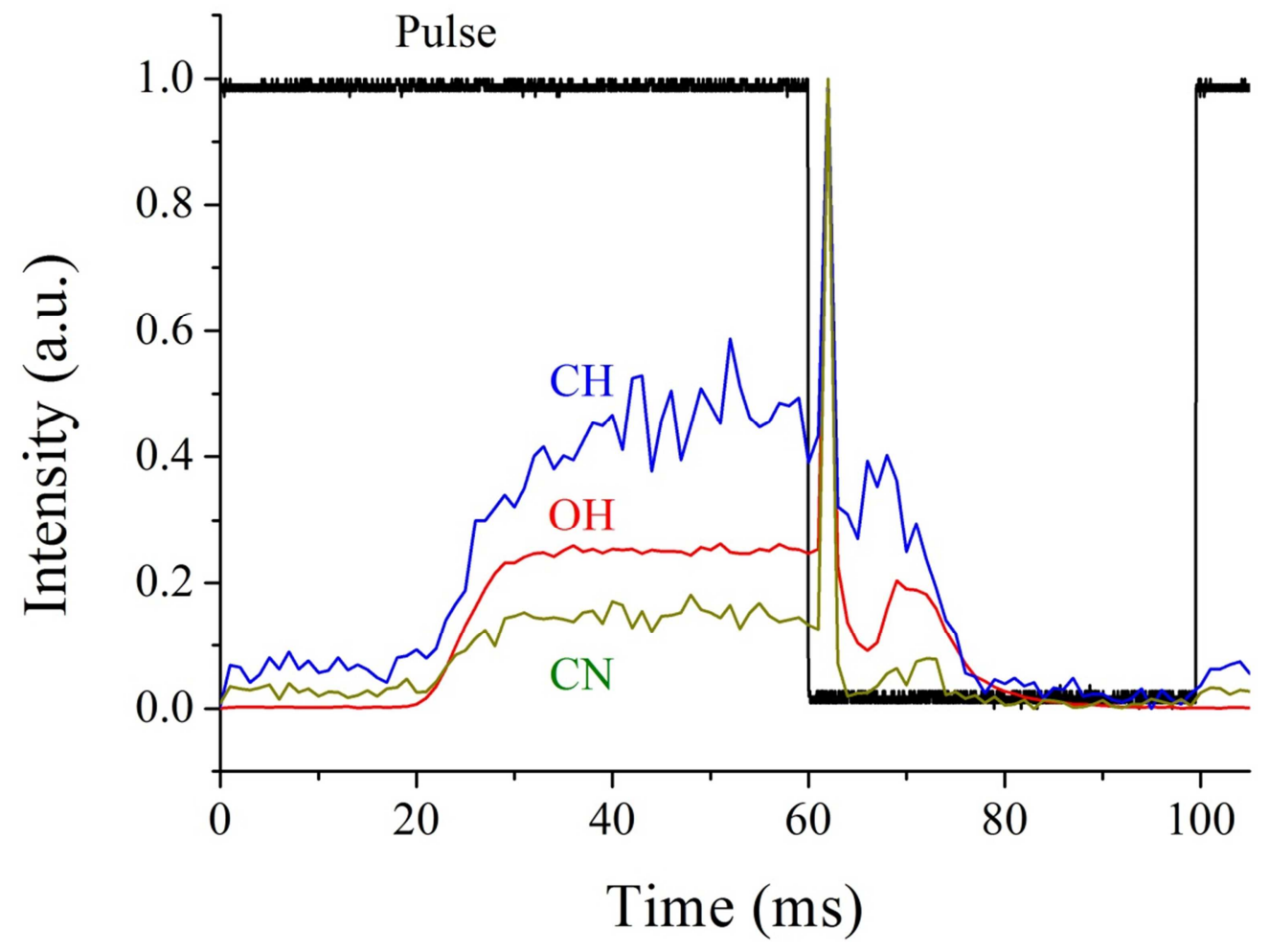

Figure 4: Time evolution of $\mathrm{CH}, \mathrm{CN}$ and $\mathrm{OH}$ normalized transitions together with the control pulse $($ Duty cycle $=60 \%, \mathrm{P}=15 \mathrm{mbar}, \mathrm{W}=250 \mathrm{~W}$, plasma gas flowrates: $\mathrm{Ar}=1050 \mathrm{sccm}$, $\mathrm{O}_{2}=100 \mathrm{sccm}$. Precursor flowrates: Ar $=30 \mathrm{sccm}$, APTES $\left.=0.13 \mathrm{sccm}\right)$. 


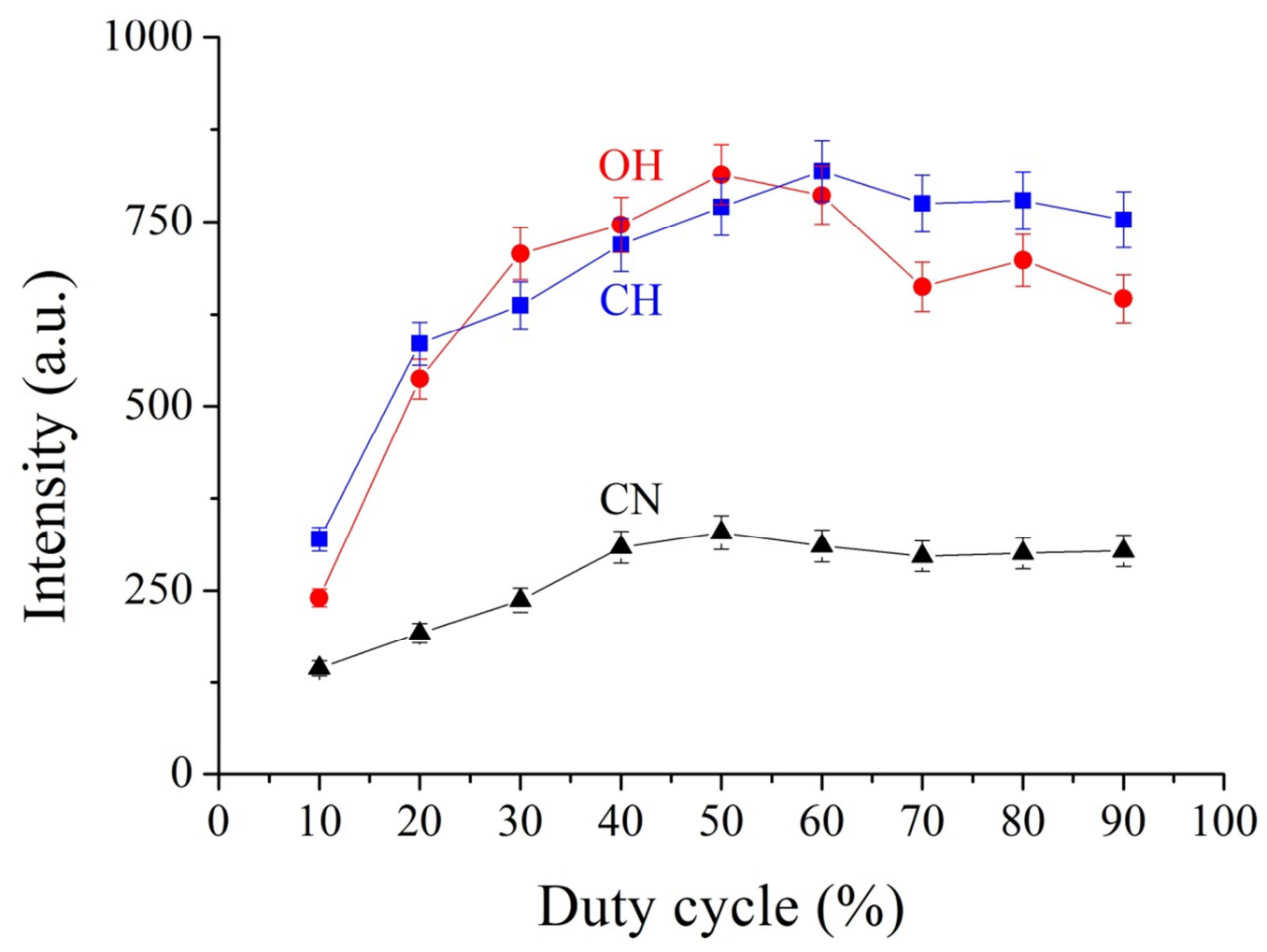

Figure 5: Evolution of $\mathrm{CH}, \mathrm{CN}$ and $\mathrm{OH}$ transitions taken $50 \mathrm{~ms}$ after the pulse rising edge as a function of the duty cycle (same conditions as in figure 4). 


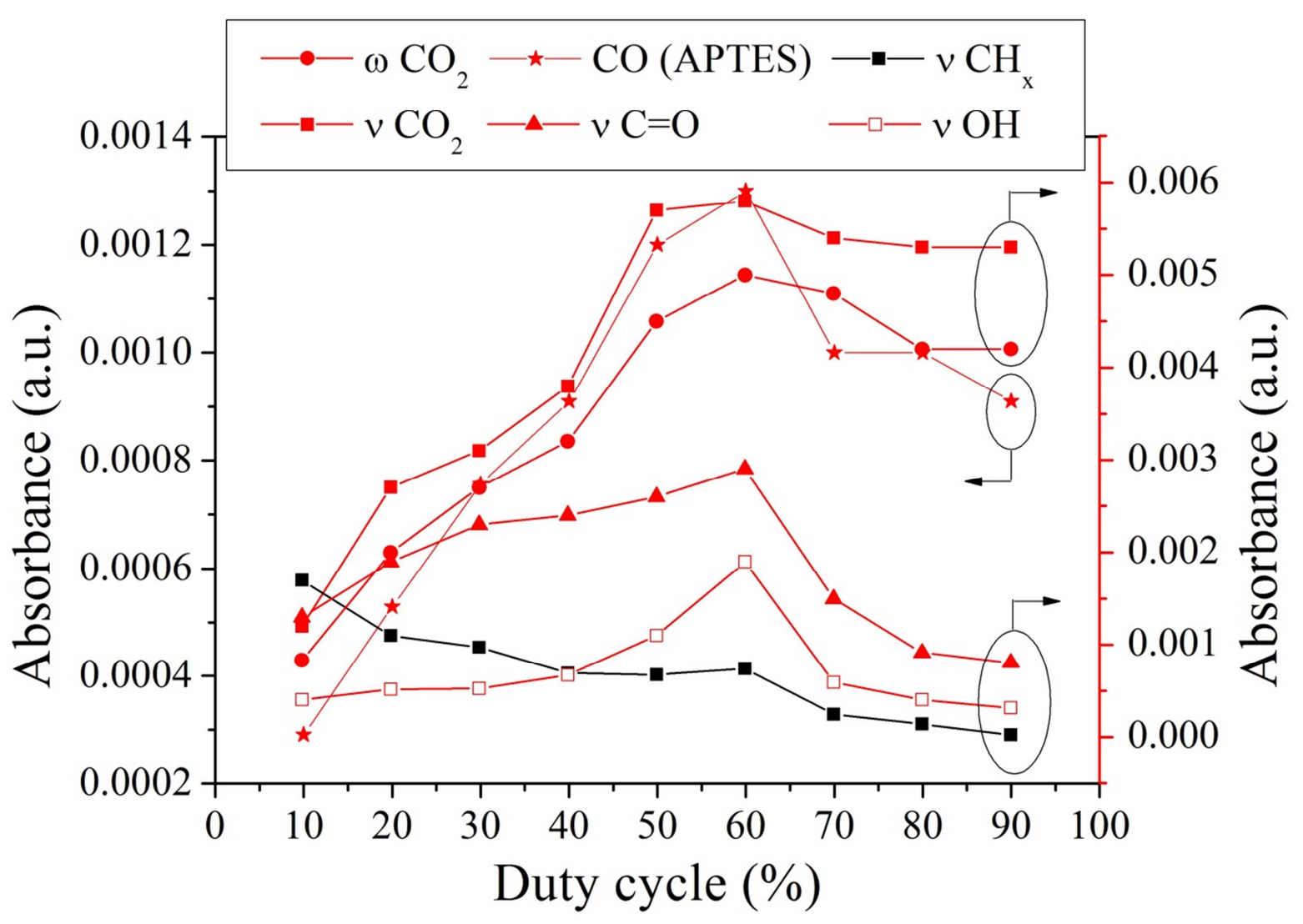

Figure 6: Evolution of the most intense FTIR absorption bands as a function of the duty cycle (same conditions as in figure 4). 


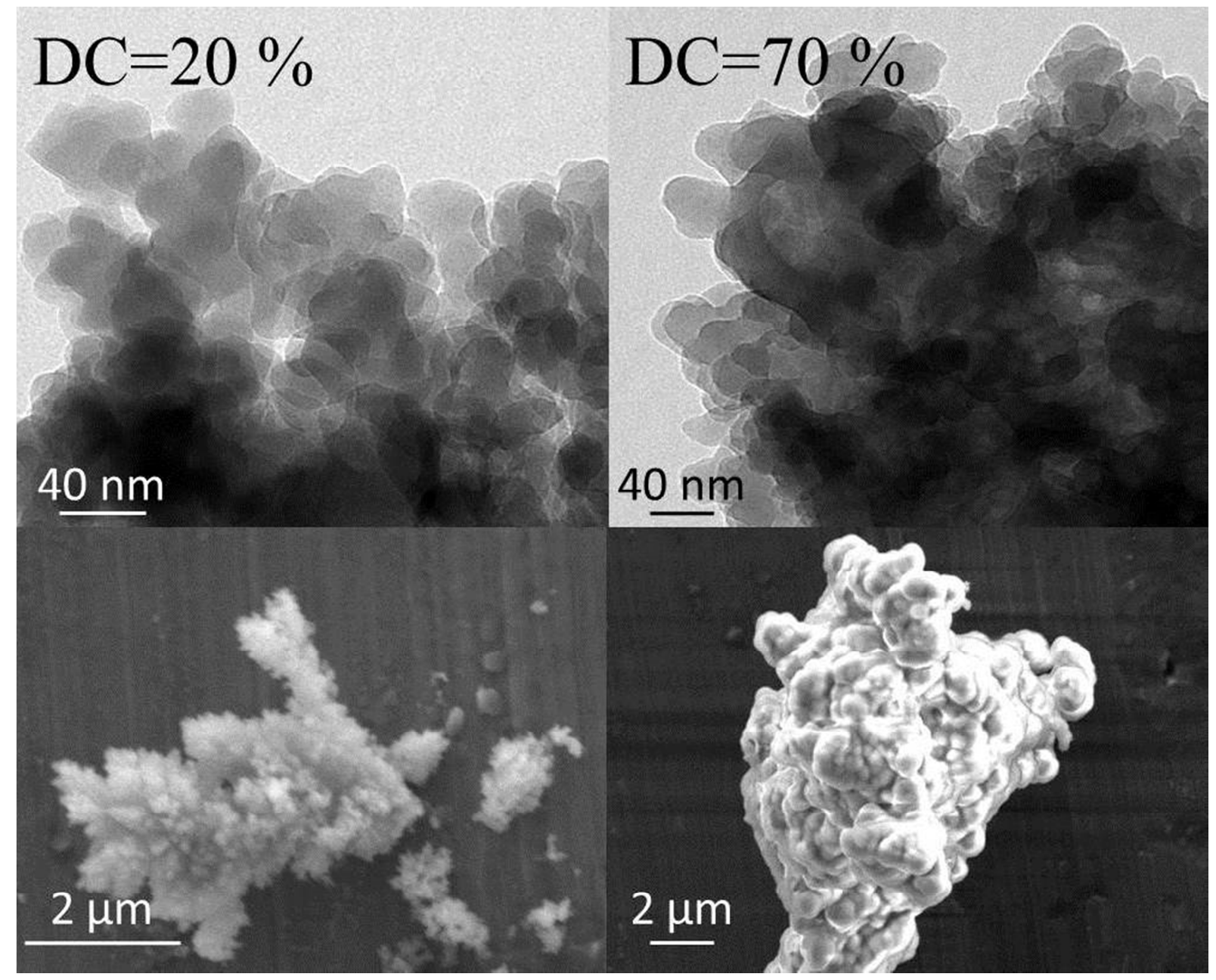

Figure 7: TEM and SEM images of nanoparticles collected on an aluminium substrate at duty cycles equal to $20 \%$ and $70 \%$. 


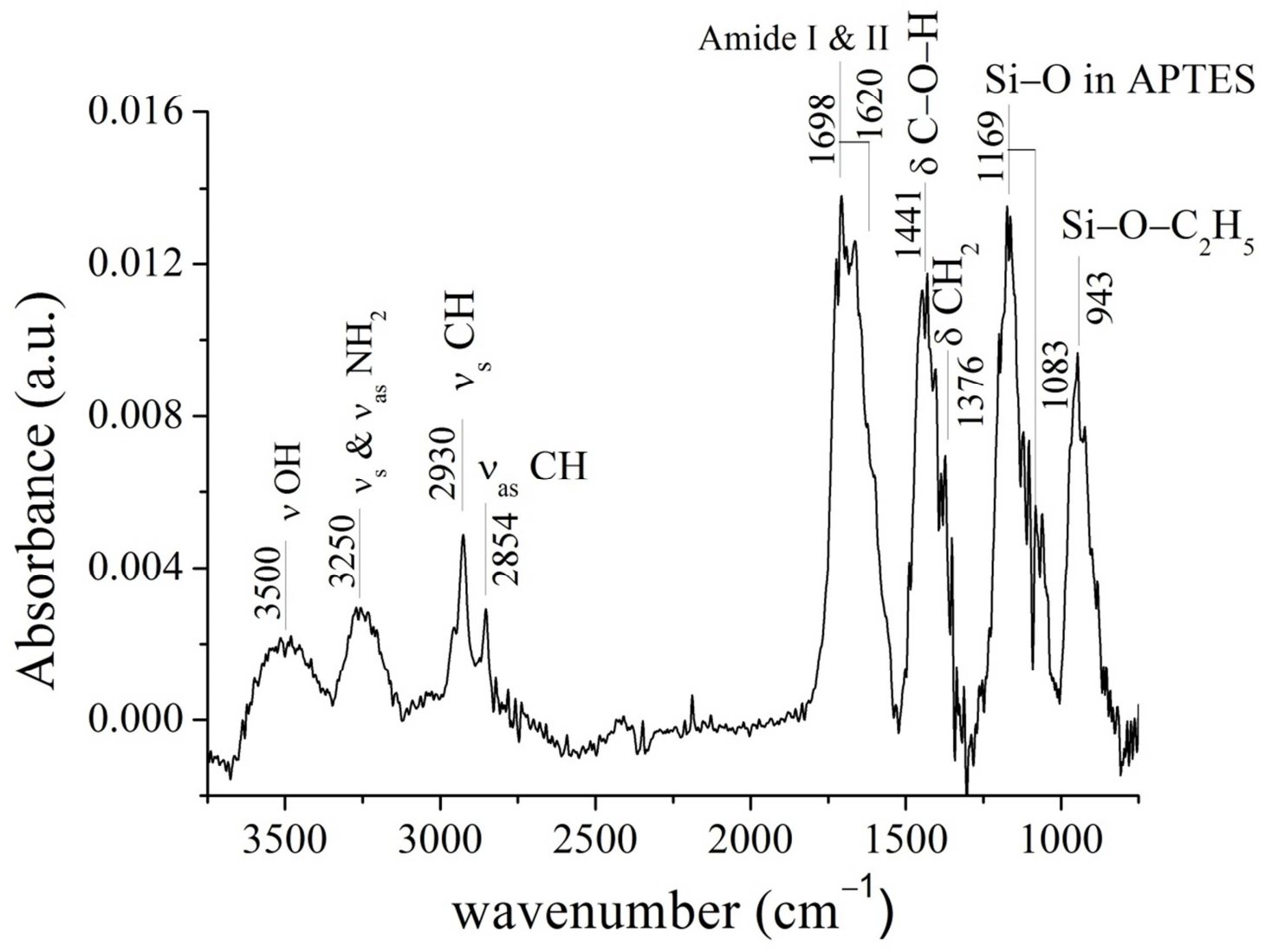

Figure 8: FTIR spectrum of solid nanoparticles collected in the gas phase at duty cycle equal to $20 \%$. Infrared region: from 3750 to $750 \mathrm{~cm}^{-1}$. Resolution: $2 \mathrm{~cm}^{-1}$. 


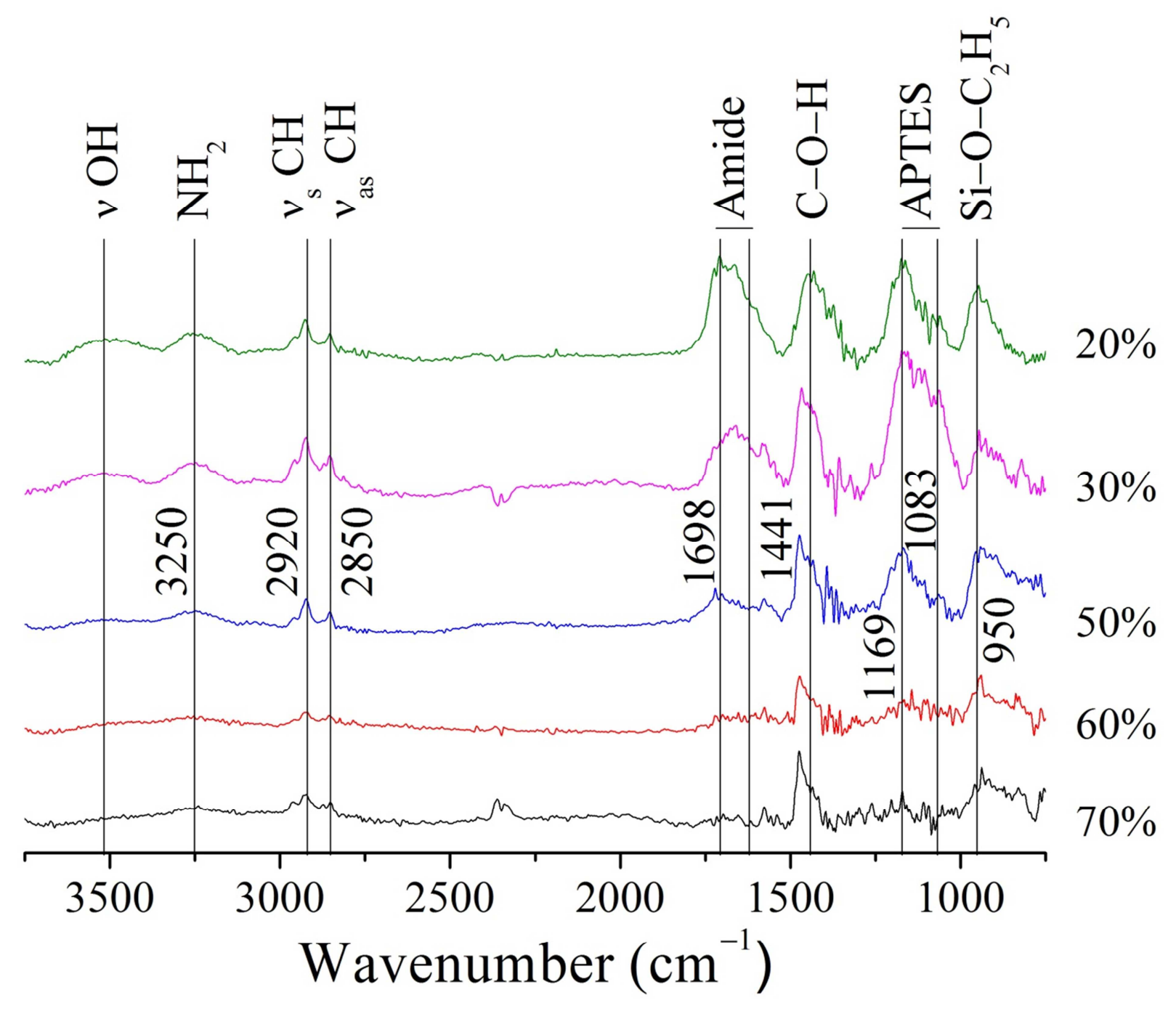

Figure 9: FTIR spectra of solid nanoparticles collected in the gas phase at different duty cycles (from 20 to $70 \%$ ). Infrared region: from 3750 to $750 \mathrm{~cm}^{-1}$. Resolution: $2 \mathrm{~cm}^{-1}$. 

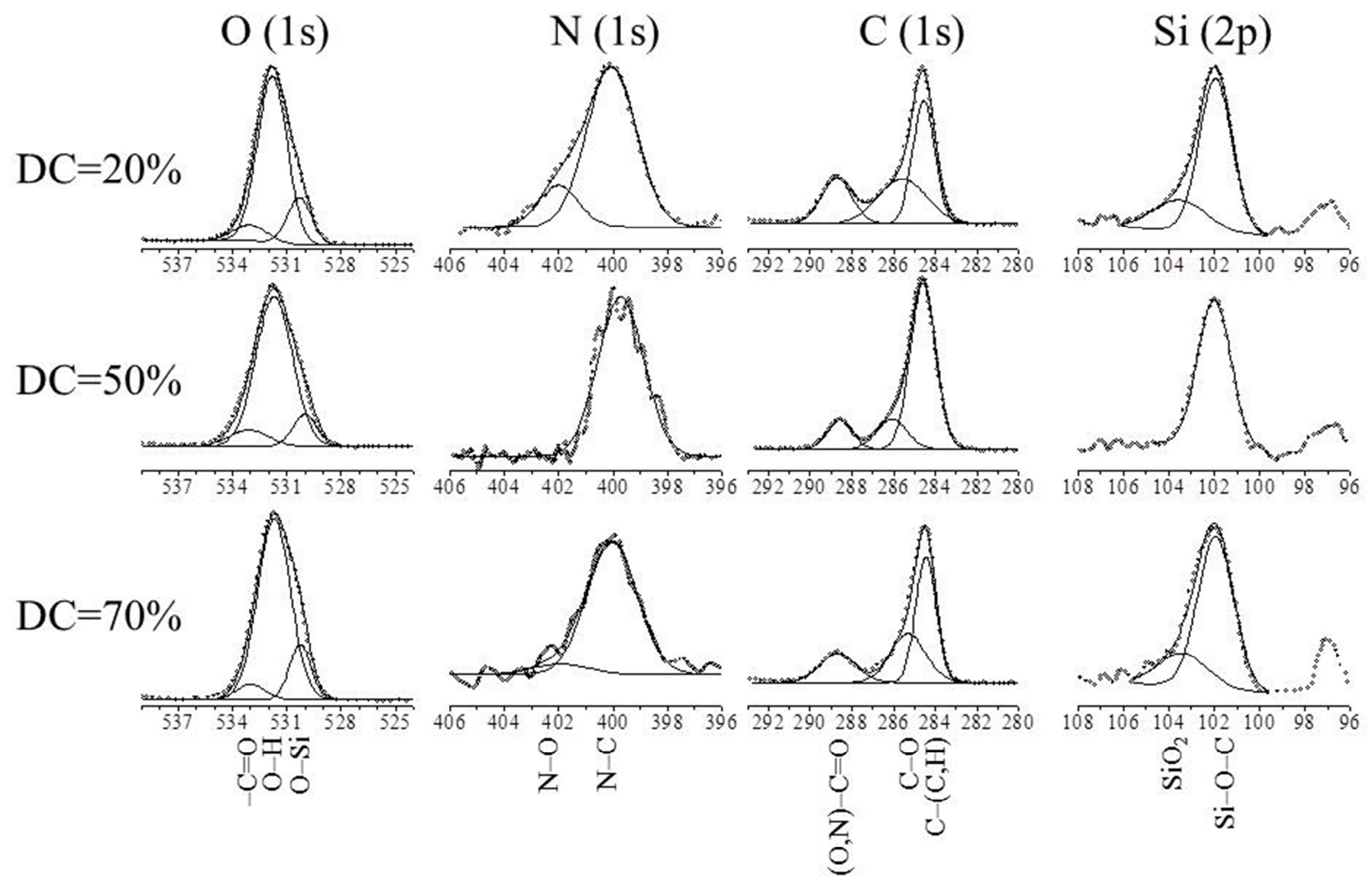

Figure 10: $\mathrm{O}(1 \mathrm{~s}), \mathrm{N}(1 \mathrm{~s}), \mathrm{C}(1 \mathrm{~s})$ and $\mathrm{Si}(2 \mathrm{p})$ XPS spectra of nanoparticles collected on an aluminium substrate for different duty cycles. 


\begin{tabular}{|c|c|c|c|c|c|}
\hline Condition & Species & Transition & System name & Intensity & $\Delta v$ \\
\hline \multirow{3}{*}{$\begin{array}{l}\text { 足 } \\
\text { 过 } \\
\frac{2}{2} \\
\frac{0}{3}\end{array}$} & $\mathrm{OH}$ & $\mathrm{OH}\left(\mathrm{A}^{2} \Sigma^{+}, v^{\prime} \rightarrow \mathrm{X}^{2} \Pi, v^{\prime \prime}\right)$ & $\AA$ A system & moderate & $\Delta v=0$ \\
\hline & $\mathrm{O}$ & $\mathrm{O}(1 \mathrm{~S} \rightarrow 1 \mathrm{D})$ & Green line & Very weak & \\
\hline & $\mathrm{O}_{2}$ & $\mathrm{O}_{2}\left(\mathrm{~b}^{1} \Sigma_{\mathrm{g}}^{+}, v^{\prime} \rightarrow \mathrm{X}^{3} \Sigma_{\mathrm{g}}^{-}, v^{\prime \prime}\right)$ & Atmospheric band & Very weak & $\Delta v=0$ \\
\hline \multirow{3}{*}{$\begin{array}{l}\text { 崩 } \\
\frac{1}{2} \\
\frac{1}{3}\end{array}$} & $\mathrm{OH}$ & $\mathrm{OH}\left(\mathrm{A}^{2} \Sigma^{+}, v^{\prime} \rightarrow \mathrm{X}^{2} \Pi, v^{\prime \prime}\right)$ & Å system & Strong & $\Delta v=-1,0$ \\
\hline & $\mathrm{CN}$ & $\mathrm{CN}\left(\mathrm{B}^{2} \Sigma^{+}, v^{\prime} \rightarrow \mathrm{X}^{2} \Sigma^{+}, v^{\prime \prime}\right)$ & $\mathrm{CN}$ violet & Moderate & $\Delta v=-1,0,+1$ \\
\hline & $\mathrm{CH}$ & $\mathrm{CH}\left(\mathrm{A}^{2} \Delta_{\mathrm{g}}, v^{\prime} \rightarrow \mathrm{X}^{2} \Pi_{\mathrm{u}}, v^{\prime \prime}\right)$ & $\mathrm{CH} 4300 \AA$ & Moderate & $\Delta v=0$ \\
\hline
\end{tabular}

Table 1: List of the transitions observed by optical emission spectroscopy in the $\mathrm{Ar}-\mathrm{O}_{2}$ afterglow with and without APTES. 


\begin{tabular}{|c|c|c|c|c|c|c|c|c|}
\hline Assignments & Frequency & Ref. & Assignments & Frequency & Ref. & Assignments & Frequency & Ref. \\
\hline$v \mathrm{H}_{2} \mathrm{O}$ & $3890 \mathrm{~cm}^{-1}$ & {$[45]$} & $v \mathrm{CO}_{2}$ & $2348 \mathrm{~cm}^{-1}$ & {$[42]$} & $v_{\text {as }} \mathrm{SiO}-\mathrm{CH}_{2}$ & $1241 \mathrm{~cm}^{-1}$ & {$[42]$} \\
\hline $\mathrm{Si}-\mathrm{OH}$ & $3674 \mathrm{~cm}^{-1}$ & {$[45]$} & $v \mathbf{C O}$ & $2140 \mathrm{~cm}^{-1}$ & {$[42]$} & $\rho \mathrm{CH}_{2}$ & $1176 \mathrm{~cm}^{-1}$ & {$[41,42]$} \\
\hline$>\mathrm{CO} \ldots \mathrm{..O}-\mathrm{H}$ & $3234 \mathrm{~cm}^{-1}$ & {$[46,47]$} & $\mathrm{Si}-\mathrm{O}$ overtones & $2116 \& 2264 \mathrm{~cm}^{-1}$ & {$[45]$} & $v_{\text {as }} \mathrm{Si}-\mathrm{O}-\mathrm{C}$ & $1110 \mathrm{~cm}^{-1}$ & {$[40]$} \\
\hline$v_{\mathrm{s}} \mathrm{CH}_{3}$ & $2987 \mathrm{~cm}^{-1}$ & {$[45]$} & $\mathrm{Si}-\mathrm{O}+\rho \mathrm{CH}_{3}$ & $1938 \mathrm{~cm}^{-1}$ & {$[44]$} & $\mathrm{Si}-\mathrm{O}$ in APTES & $1065 \mathrm{~cm}^{-1}$ & {$[37,38,42]$} \\
\hline$v_{\mathrm{s}} \mathrm{CH}_{2}$ & $2939 \mathrm{~cm}^{-1}$ & {$[41,45]$} & $\vee \mathbf{C}=\mathbf{O}$ & $1744 \mathrm{~cm}^{-1}$ & {$[42]$} & $\mathrm{Si}-\mathrm{O}-\mathrm{C}_{2} \mathrm{H}_{5}$ & $958 \mathrm{~cm}^{-1}$ & {$[42]$} \\
\hline $\mathrm{v}_{\mathrm{as}} \mathrm{CH}_{3}$ & $2899 \mathrm{~cm}^{-1}$ & {$[45]$} & $\delta \mathrm{NH}$ & $1615 \mathrm{~cm}^{-1}$ & [39] & $\rho \mathrm{CH}_{3}$ & $878 \mathrm{~cm}^{-1}$ & {$[42]$} \\
\hline $\mathrm{v}_{\mathrm{as}} \mathrm{CH}_{2}$ & $2870 \mathrm{~cm}^{-1}$ & {$[41,45]$} & $\delta \mathrm{H}-\mathrm{C}-\mathrm{H}$ & $1449 \& 1475 \mathrm{~cm}^{-1}$ & {$[36,43]$} & $\omega \mathrm{NH}_{2}$ & $785 \mathrm{~cm}^{-1}$ & {$[38]$} \\
\hline $\mathrm{Si}-\mathrm{OH} \ldots \mathrm{NH}_{2}$ & $2745 \mathrm{~cm}^{-1}$ & {$[40]$} & $\delta \mathrm{CH}_{2}$ (distant from $\mathrm{Si}$ ) & $1394 \mathrm{~cm}^{-1}$ & {$[38,39]$} & $\delta \mathrm{CO}_{2}$ & $667 \mathrm{~cm}^{-1}$ & {$[46]$} \\
\hline
\end{tabular}

Table 2: Vibrational groups and their corresponding frequencies observed in the APTES flow with (bold) and without Ar- $\mathrm{O}_{2}$ afterglow. 


\begin{tabular}{|c|c|c|c|c|c|c|c|}
\hline Assignment & Comment & Frequency & Ref. & Assignment & Comment & Frequency & Ref. \\
\hline $\mathrm{Si}-\mathrm{O}-\mathrm{C}_{2} \mathrm{H}_{5}$ & strong & $943 \mathrm{~cm}^{-1}$ & [42] & v CO (amide I) & strong & $1698 \mathrm{~cm}^{-1}$ & [46] \\
\hline $\mathrm{Si}-\mathrm{O}$ in APTES & shoulder & $1083 \mathrm{~cm}^{-1}$ & [42] & $\mathrm{v}_{\mathrm{as}} \mathrm{CH}_{3}$ & & $2851 \mathrm{~cm}^{-1}$ & {$[41,45]$} \\
\hline $\mathrm{Si}-\mathrm{O}$ in APTES & strong & $1169 \mathrm{~cm}^{-1}$ & [42] & $v_{\mathrm{s}} \mathrm{CH}_{3}$ & & $2930 \mathrm{~cm}^{-1}$ & {$[41,45]$} \\
\hline$\delta \mathrm{CH}_{2}$ & shoulder & $1376 \mathrm{~cm}^{-1}$ & {$[36,43]$} & $v_{\mathrm{s}} \mathrm{NH}_{2} ; \mathrm{v}_{\mathrm{as}} \mathrm{NH}_{2}$ & very broad & $3120-3350 \mathrm{~cm}^{-1}$ & [46] \\
\hline$\delta \mathrm{C}-\mathrm{O}-\mathrm{H}$ & strong & $1441 \mathrm{~cm}^{-1}$ & [46] & $v \mathrm{OH}$ & very broad & $3350-3680 \mathrm{~cm}^{-1}$ & [46] \\
\hline$\delta \mathrm{NH}_{2}$ (amide II) & shoulder & $1620 \mathrm{~cm}^{-1}$ & {$[46]$} & & & & \\
\hline
\end{tabular}

Table 3: Main vibrational groups and their corresponding frequencies observed in nanoparticles produced from APTES for different duty cycles (from 20 to $70 \%$ ). 
SUPPLEMENTAL MATERIALS 

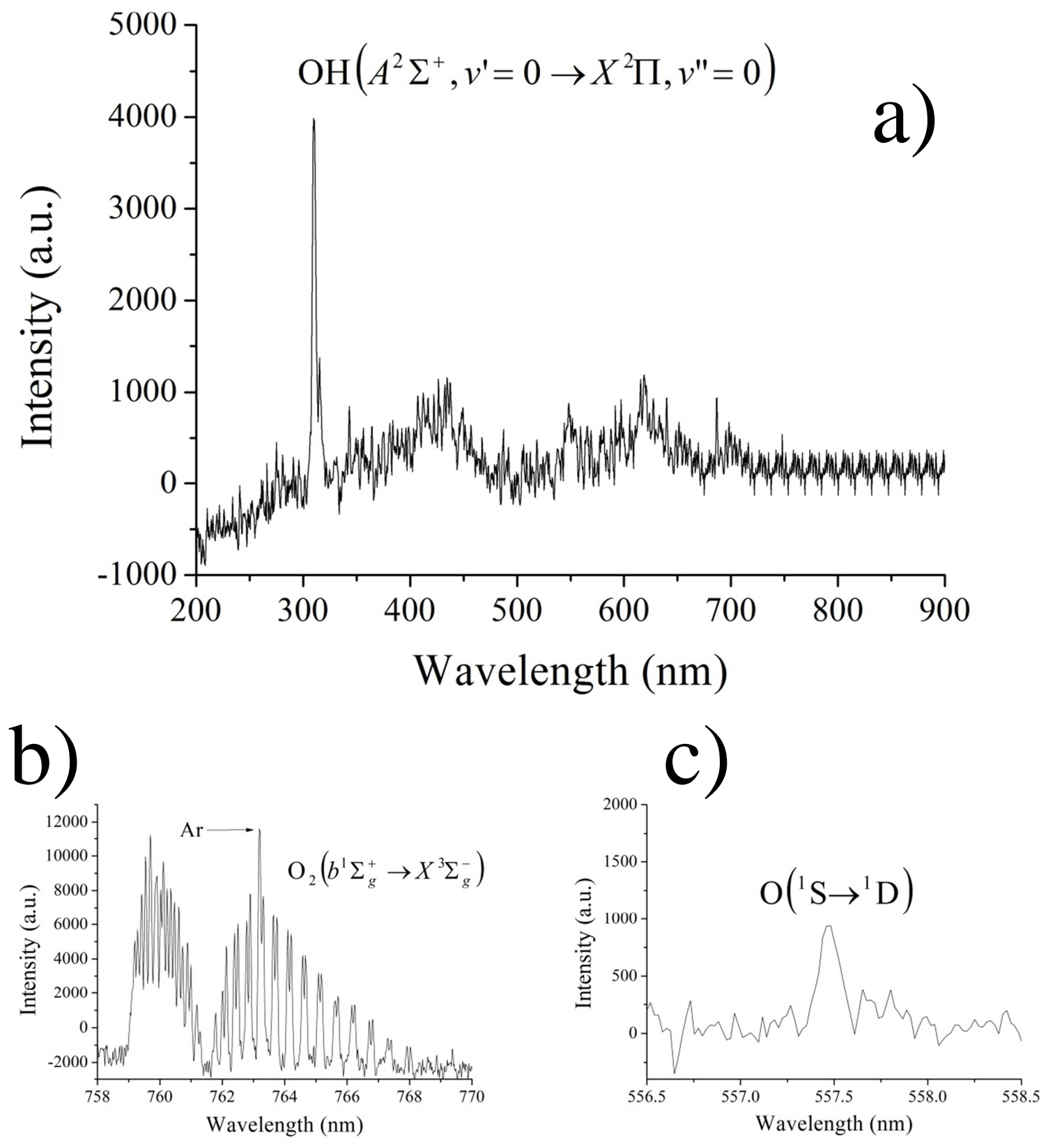

Supplemental material 1: a) OES spectrum of the $\mathrm{Ar}-\mathrm{O}_{2}$ post-discharge showing principally the $\mathrm{OH}$ emission at $306 \mathrm{~nm}$. b) Detail of the atmospheric band (an argon line due to an unwanted reflection from the plasma is present in the middle of the spectrum and must be removed for any simulation of the rotational spectrum). c) Detail of the green line. 


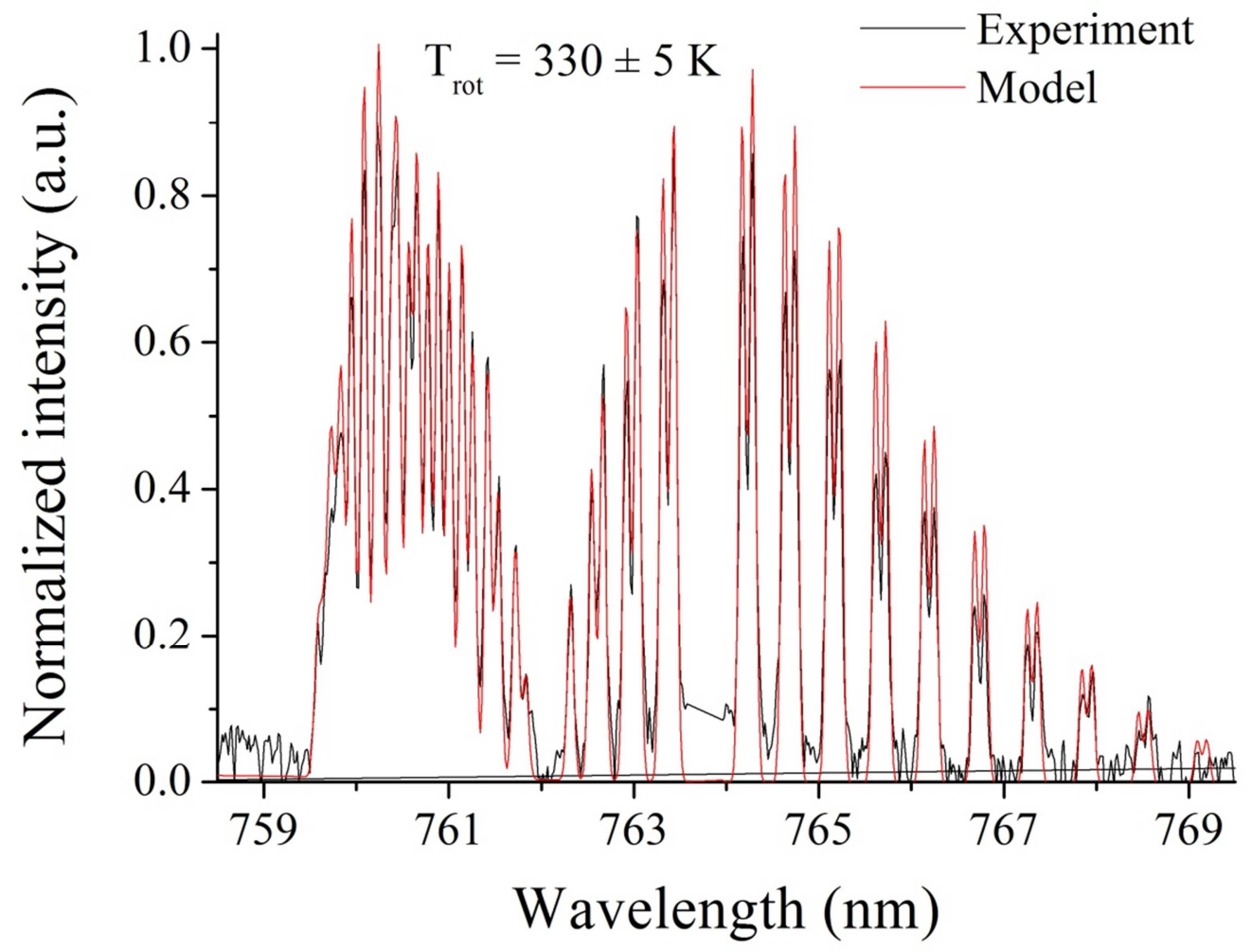

Supplemental material 2: Modelling of the rotational spectrum of the $\Delta v=0$ transition at $762 \mathrm{~nm}$ of the atmospheric band to determine the gas temperature (the argon line appearing in the spectrum has been removed). 

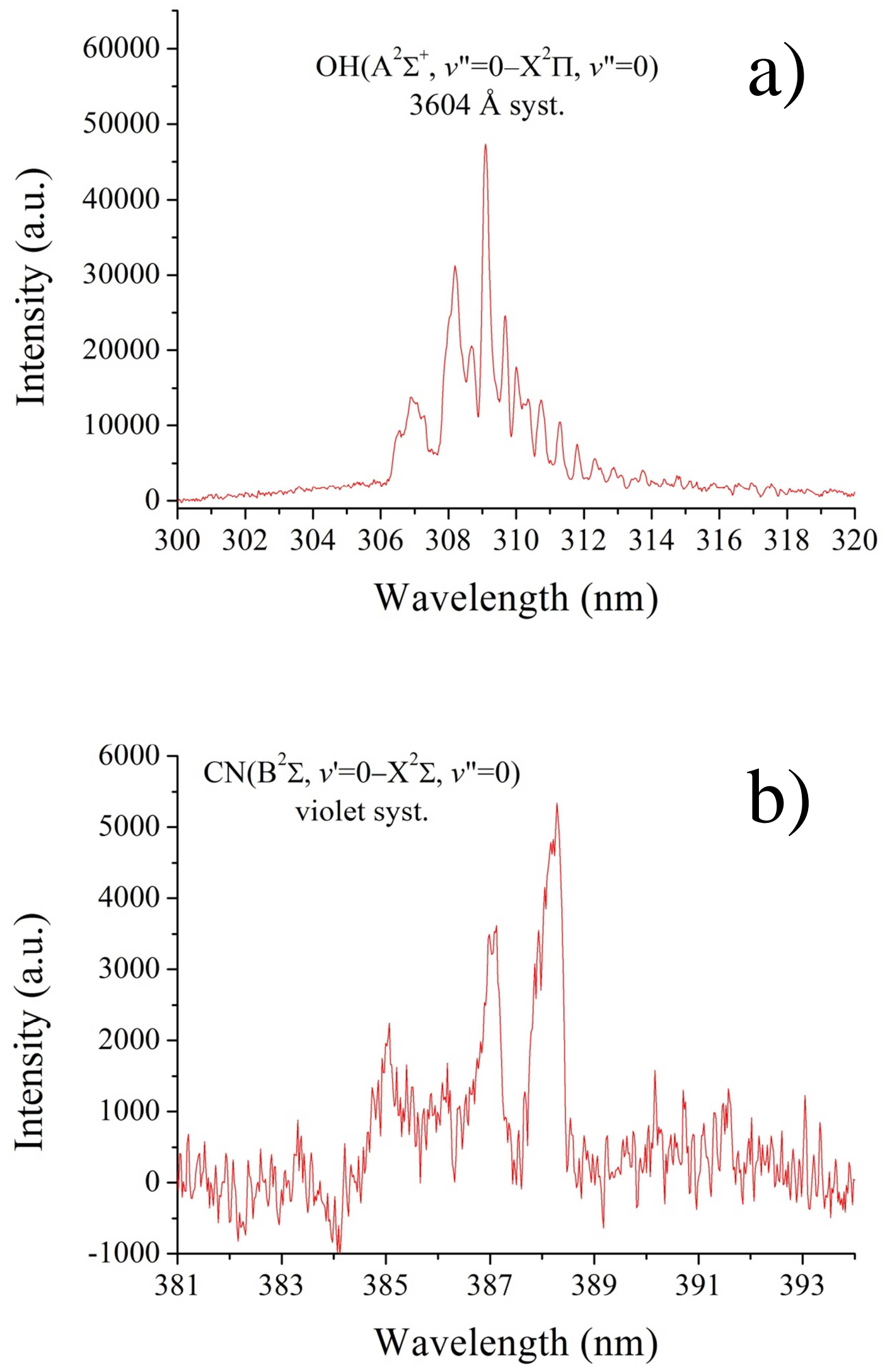


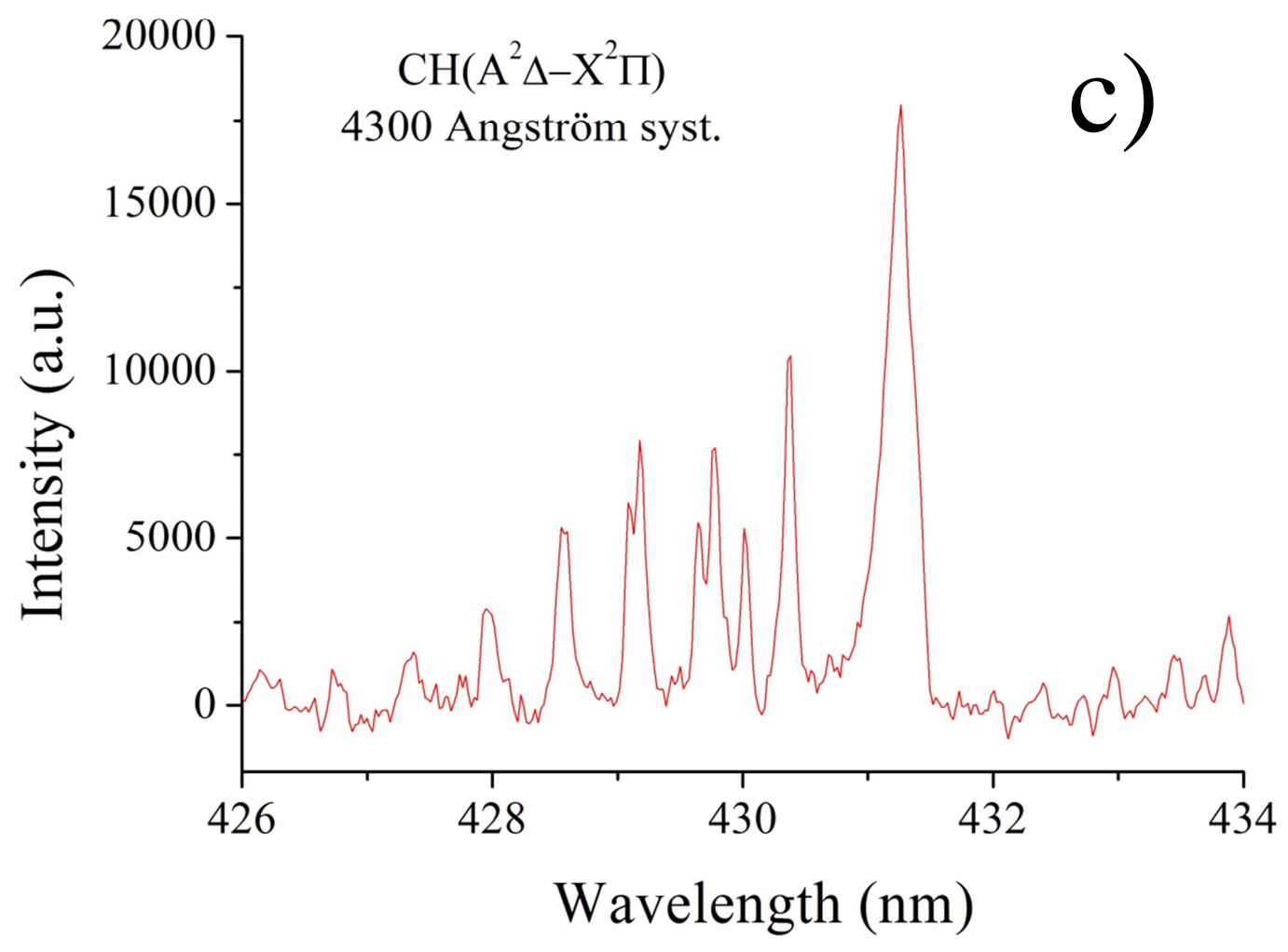

Supplemental material 3: a) OES spectrum showing the $\mathrm{OH}$ emission at $306 \mathrm{~nm}$ in the Ar$\mathrm{O}_{2}$ post-discharge with APTES. b) Idem for $\mathrm{CN}$ at $388 \mathrm{~nm}$. c) Idem for $\mathrm{CH}$ at $432 \mathrm{~nm}$ 


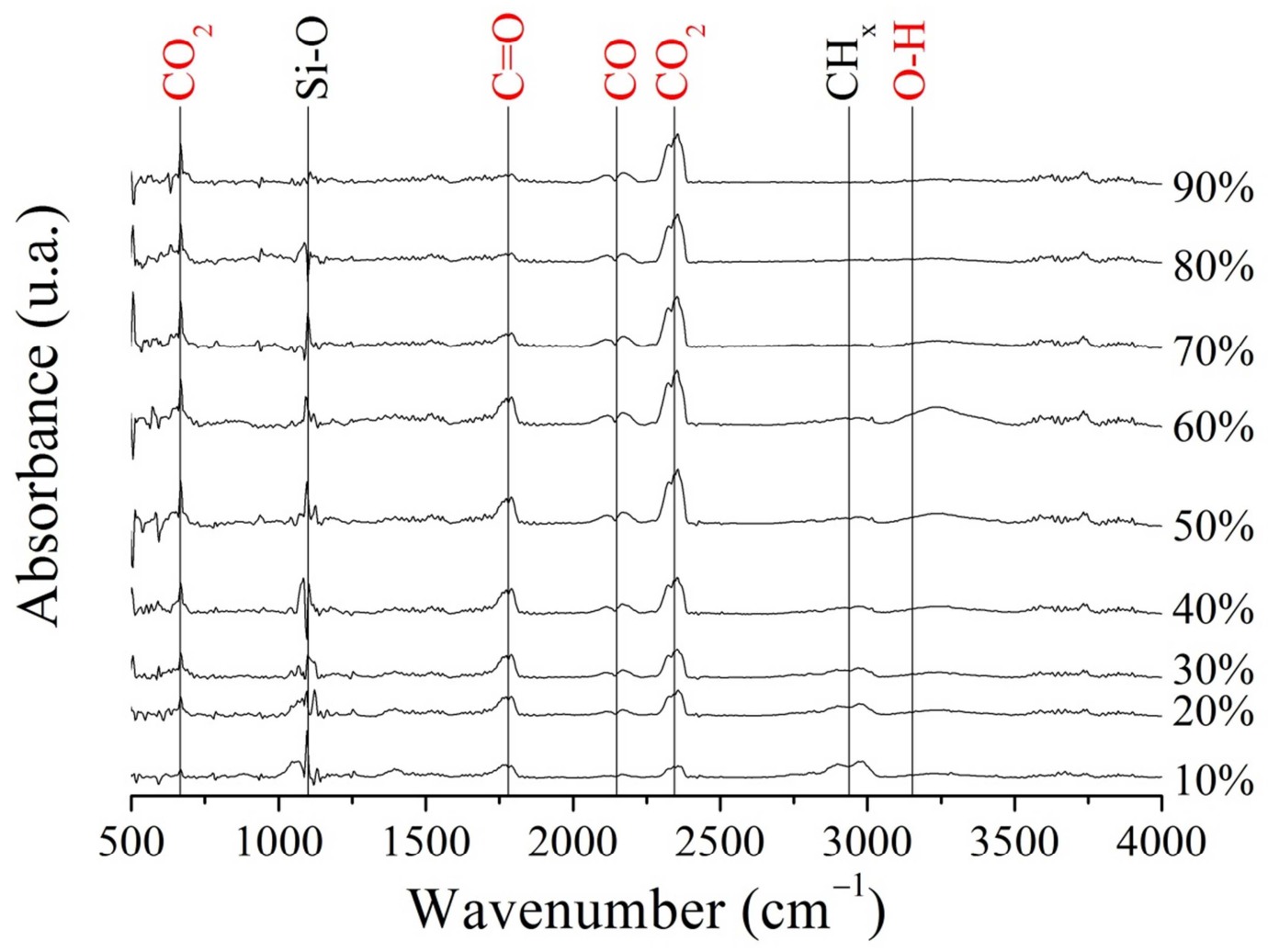

Supplemental material 4: Evolution of FTIR spectra recorded in an APTES-Ar- $\mathrm{O}_{2}$ afterglow for various duty cycle (resolution $8 \mathrm{~cm}^{-1}, \mathrm{P}=15 \mathrm{mbar}, \mathrm{W}=250 \mathrm{~W}$, flowrates: $\mathrm{Ar}$ $=1050 \mathrm{sccm}, \mathrm{O}_{2}=100 \mathrm{sccm}, \mathrm{Ar}=30 \mathrm{sccm}$, APTES $\left.=0.13 \mathrm{sccm}\right)$ 


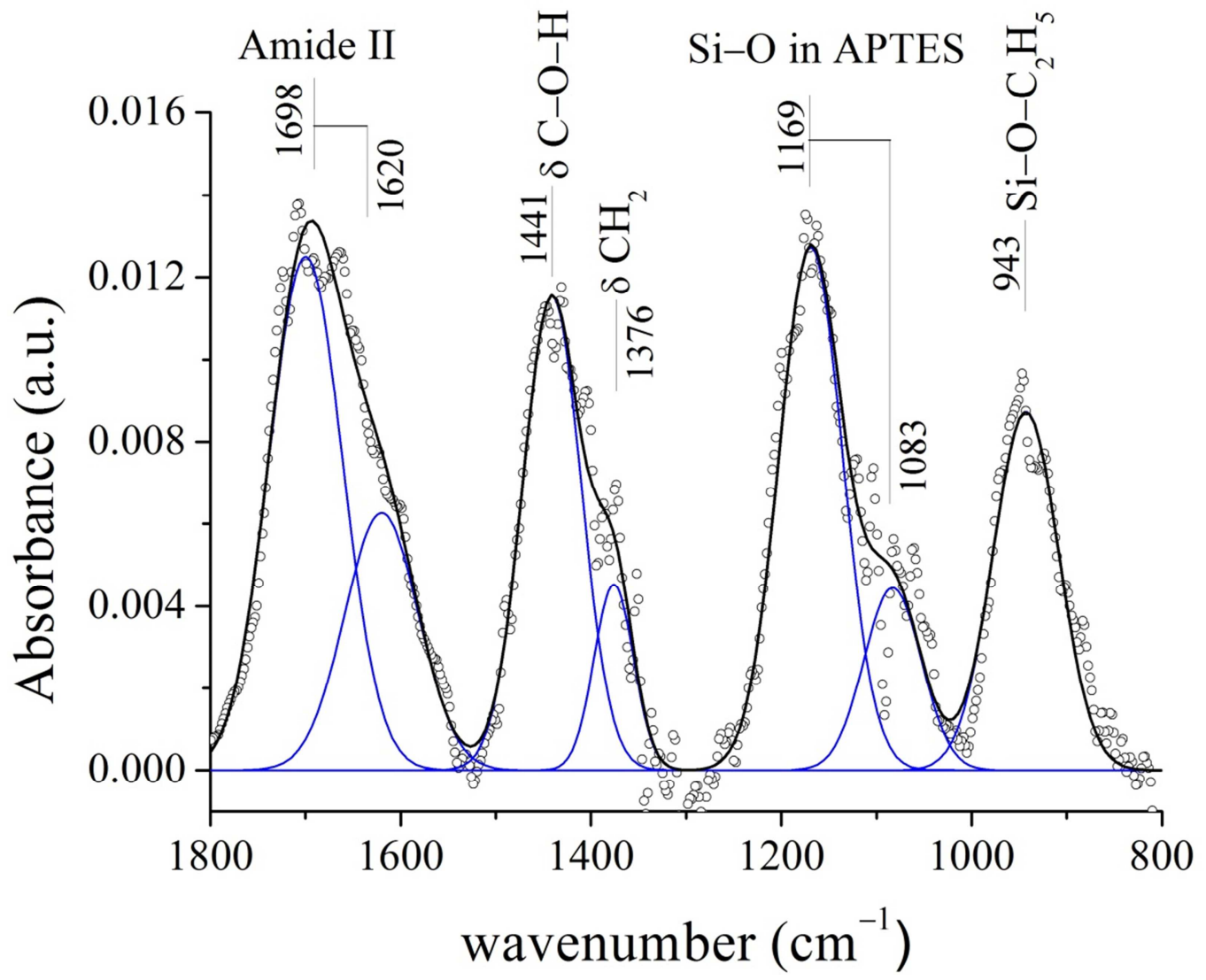

Supplemental material 5: Deconvolution of absorption bands between 1800 and $800 \mathrm{~cm}^{-1}$ for nanoparticles grown in an APTES-Ar-O $\mathrm{O}_{2}$ afterglow (resolution $8 \mathrm{~cm}^{-1}, \mathrm{DC}=20 \%, \mathrm{P}=15$ mbar, $\mathrm{W}=250 \mathrm{~W}$, flowrates: $\mathrm{Ar}=1050 \mathrm{sccm}, \mathrm{O}_{2}=100 \mathrm{sccm}, \mathrm{Ar}=30 \mathrm{sccm}$, APTES $=0.13$ sccm). 

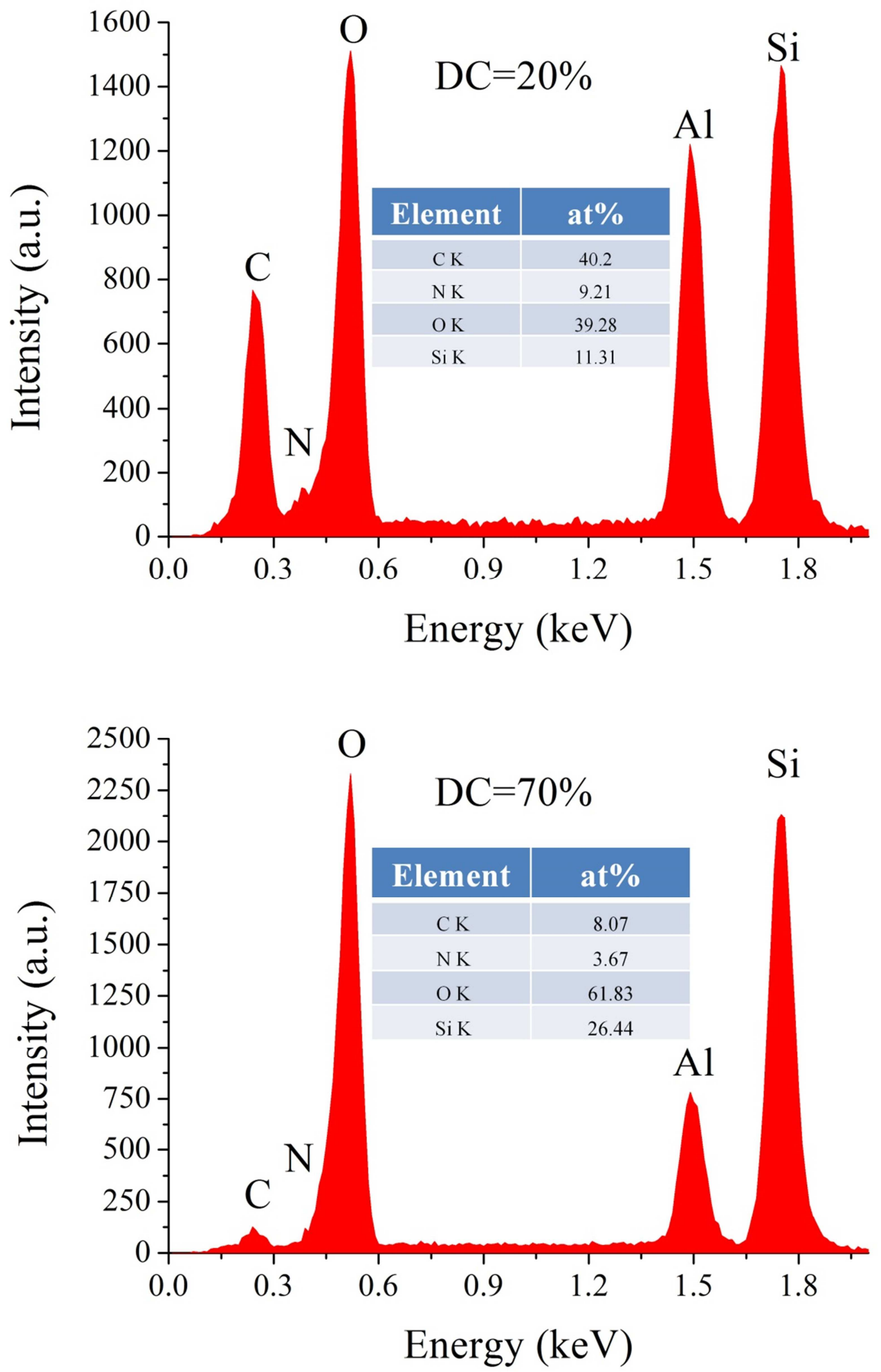

Supplemental material 6: EDX analyses of powders collected on an aluminium substrate for duty cycles equal to 20 and $70 \%$. $\left(\mathrm{P}=15 \mathrm{mbar}, \mathrm{W}=250 \mathrm{~W}\right.$, flowrates: $\mathrm{Ar}=1050 \mathrm{sccm}, \mathrm{O}_{2}=$ $100 \mathrm{sccm}, \mathrm{Ar}=30 \mathrm{sccm}$, APTES $=0.13 \mathrm{sccm})$ 